\title{
The role of remittances inflow, renewable and non- renewable energy consumption in the environment: accounting ecological footprint indicators for top remittance-receiving countries
}

Liping Zhang ( $\sim$ zlp2007@gdut.edu.cn )

Guangdong University of Technology

Bo Yang

Zhongnan University of Economics and Law

Atif Jahanger

Zhongnan University of Economics and Law

\section{Research Article}

Keywords: Ecological Footprint, Remittance inflows, EKC hypothesis, Top remittances countries

Posted Date: May 11th, 2021

DOI: https://doi.org/10.21203/rs.3.rs-456013/v1

License: (1) (i) This work is licensed under a Creative Commons Attribution 4.0 International License.

Read Full License

Version of Record: A version of this preprint was published at Environmental Science and Pollution Research on October 11th, 2021. See the published version at https://doi.org/10.1007/s11356-02116545-z. 
The role of remittances inflow, renewable and non-renewable energy consumption in the environment: accounting ecological footprint indicators for top remittance-receiving countries

\author{
Liping Zhang ${ }^{a}$, Bo Yang ${ }^{b}$, Atif Jahanger ${ }^{b, *}$
}

\author{
Liping Zhang a \\ ${ }^{a}$ Department of Culture Communication, \\ General Education Center, Guangdong University of Technology, Guangzhou 510006, \\ China. \\ (LZ: Email: zlp2007@gdut.edu.cn)
}

\author{
Bo Yang ${ }^{b}$ \\ School of Economics, \\ Zhongnan University of Economics and Law, Wuhan 430073, China \\ (AJ: https://orcid.org/0000-0003-0210-0606 \\ (BY: yangbo21cn@163.com ) \\ Atif Jahanger ${ }^{\mathbf{b}}$, * (corresponding author) \\ School of Economics, \\ Zhongnan University of Economics and Law, Wuhan 430073, China \\ (AJ: atif_jahanger@hotmail.com , +86-13007117145) \\ ORCID ID: http://orcid.org/0000-0002-0270-1367 \\ * Correspondence: Atif Jahanger; atif_jahanger@hotmail.com
}




\title{
The role of remittances inflow, renewable and non-renewable energy consumption in the environment: accounting ecological footprint indicators for top remittance-receiving countries
}

\begin{abstract}
This study determines the dynamic linkages between remittances inflow, foreign direct investment, and ecological footprint in top ten remittance-receiving counties in the presence of economic growth and renewable and non-renewable energy under the framework of Environmental Kuznets Curve (EKC) hypothesis over the period of 1990-2018 by employing the continuously updated fully modified (CUP-FM) and the continuously updated biascorrected (CUP-BC) estimators. The results show that remittances inflow, foreign direct investment, and non-renewable energy utilization affect the ecological footprint positively while renewable energy utilization negatively impacts on ecological footprint. This study also supports the pollution haven hypothesis and inverted U-shaped EKC hypothesis. Furthermore, in order to account for the national heterogeneity, we have executed a country-wise EKC hypothesis, the results of the full modified ordinary least square (FMOLS) support the inverted U-shaped EKC hypothesis in the case of Bangladesh, China, France, India, Pakistan, and Vietnam while displaying a U-shaped curve in Germany, Mexico, and Nigeria. Besides, the results are robust to various robustness analyses that we have executed for inspection of the reliability of our main findings. Finally, this study presents important policy implications with respect to top remittance-receiving countries.
\end{abstract}

Keywords: Ecological Footprint; Remittance inflows; EKC hypothesis; Top remittances countries

\section{1- Introduction}

Today rethinking environmental regulation remains at the forefront of academic debate and social medial. Already scientists have warned that if the level of pollution continued, this might attract physical risk, reduce productivity, and prolonged economic growth. Meanwhile, 
the International Panel on Climate Change (IPCC) has made a serious effort to promote environmental sustainability by strengthening regulations that will reduce carbon $\left(\mathrm{CO}_{2}\right)$ emissions (IPCC, 2019). Despite the commitment of IPCC, the optimal reduction in carbon emissions is far from being achieved. What is unclear is whether the success of IPCC in ensuring compliance has led to the increase in carbon emissions or perhaps, the major carbonemitting nation failed to promote environmental quality. In the existing published literature, a lot of scholars such as Yang et al., 2020; Lv and Li. (2021); Shen et al., (2021); Safi et al. (2021) have used $\mathrm{CO}_{2}$ emission as an indicator of environmental quality. However, $\mathrm{CO}_{2}$ emissions as a proxy of environmental degradation do not cautious the resources, i.e., gas, oil, forest, soil, and fishing (Usman and Jahanger 2021). In this situation, ecological footprint (EFP) is broadly known as a more inclusive proxy of environmental decay (Yang et al., 2021a; 2021b; Usman et al., 2020a; 2020b; 2020c). The EFP is compressed of six kinds of areas such as carbon footprint, build-up land, grazing land, forest land, cropland, and fishing grounds that define the broad concept of environmental sustainability. EFP is an important indicator of the environmental impact of humans and provides metrics to assess how strict environmental policies are in order to promote sustainability (Nathaniel et al., 2021).

Remittance flows have become an increasingly essential part of the universal economy and a potential source of income for many countries. ${ }^{1}$ Remittance inflow has been considered as one of the critical sources of fund/subsidy, susceptive to attaining the sustainable development Goals (SDG) definite in the post-2015 Agenda of the United Nations Development Programme (UNDP 2015). Remittance inflow could enhance buying power, making it easier to attain household accessories (i.e., automotive vehicles, electric machines, and vehicles, etc) and thus putting more pressure on energy utilization and environmental degradation. According to the world bank (2019), these ten major remittances-receiving countries such as India (83332078002US\$), Mexico (39021789685US\$). Philippines (35167471832US\$), France (26837550754US\$), Egypt (26781400000US\$), Nigeria (23809281401US\$), Pakistan (22245000000US\$), Bangladesh (18362675926US\$), China (18294313104US\$), Vietnam (17000000000US\$) and contributing proximately more than 2/4 of the total environment pollution (BP, 2019). Therefore, it is essential to investigate the impact of remittances inflow on the EFP in these countries to recommend suitable policy implications.

\footnotetext{
${ }^{1}$ See More detail: https://pubdocs.worldbank.org/en/419881444766663419/Remittancess-DevelopmentImpcatFutureProspects.pdf
} 
One of the key aspects of environmental deprivation is the level of economic growth. The inverted U-shaped relationship Environmental Kuznets Curve (EKC) hypothesis that occurs between environmental degradation and economic growth was first confirmed by Grossman and Krueger (1991). The relationship shows that environmental degradation enhances at the initial stage as the level of economic growth rises and then economic growth decreases environmental pollution when a certain threshold is passed. This relationship can be shown in Fig. 1. Energy plays a vital role in economic development and environmental degradation. A large amount of energy utilization in the production processes or economic activities leads to enhance environmental degradation (Yang et al., 2020). According to statistics from the world bank (2019), the contribution of top remittances countries to energy utilization increases from 55.12501 US\$ in 1990 to 65.65632 US\$ (10.53\%) in 2014. Meanwhile, the rapidly growing energy utilization and fossil fuel-based energy structure have generated huge challenges associated with environmental pressures across the top remittance countries.

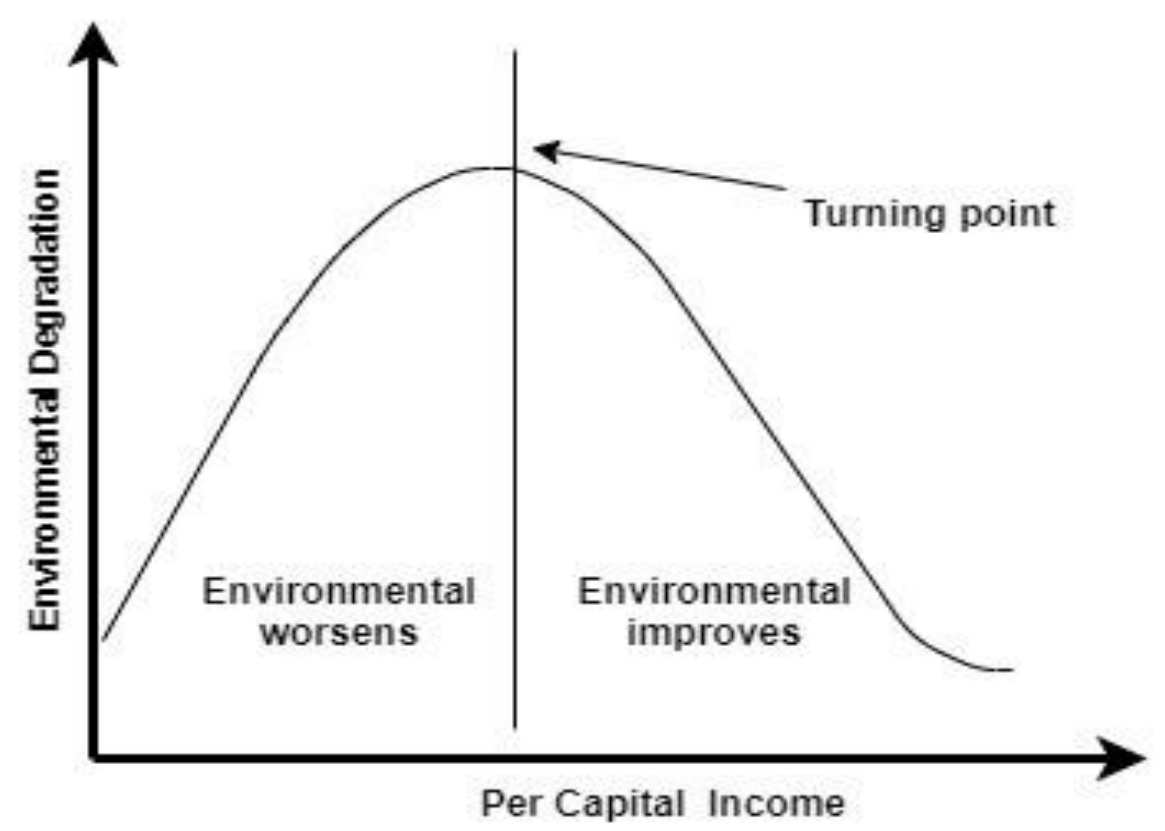

Fig.1 Environmental Kuznets Curve

Foreign direct investment (FDI) is a significant element of economic growth, particularly when national savings are not enough to deal with national investments (OECD, 2002). Researchers investigate that FDI supports environmental quality with eco-friendly technologies (Essandoh et al., 2020). Latest researches deliberate on the pollution-haven hypothesis, suggesting that a less role and regulation about the environment in a host country 
will attract multinational companies through FDI which leads to degradation of the environmental quality in the country (Yang et al., 2020). However, the nexus between environmental degradation and FDI is still questionable due to the pollution-halo hypothesis. The pollution halo hypothesis suggests that universal eco-friendly(green) technologies transfer through FDI inflow that enhances the environmental quality (Balsalobre-Lorente et al., 2019).

This study contributes to the existing literature in third-folds. First, this study is to explore the effects of remittances inflow, renewable and non-renewable energy utilization over ecological footprint during 1990-2016 under the framework of the Environmental Kuznets Curve (EKC) hypothesis. Second, to the best of the author's information, this is the first study that takes into account the impact of remittances inflow on the ecological footprint in the top ten remittances-receiving countries. Third, after confirming the possible cross-sectional dependency (CSD), this study used a second-generation more advance econometric technique (i.e., CADF and CIPS unit root test, Westerlund cointegration test, and panel Dumitrescu and Hurlin non-causality test). For long-run elasticity, this study used continuously updated fully modified (CUP-FM) and continuously updated bias-corrected (CUP-BC) models. These approaches are useful in producing consistent estimates even when CSD, autocorrelation, endogeneity, fractional integration, heteroscedasticity exist in panel data and give more valuable policy implications for top remittances-receiving countries.

The rest of the study is organized as follows. Section 2 presents a concise literature review, while section 3 describes data, empirical strategy, and methodology. Section 4 presents the empirical results and discuss the findings, while section 5 concludes with policy recommendation and suggestion for future research.

\section{2- Literature review}

The nexus between remittances inflow, remittances inflow, renewable, and nonrenewable energy utilization, economic growth, and ecological footprint have been separated into these sub-headings (1) Remittances inflow-environmental nexus (2) Renewable-nonrenewable energy utilization-environment nexus (3) Economic growth-foreign direct investment-environment.

\subsection{Remittances inflow-environment nexus:}

Remittance inflow plays an essential part in accelerating economic growth and is also considered a key factor of income source for any economy (De and Ratha. 2012). Remittance inflow has an important source of the financial sector and increases the environmental 
degradation by providing funds or loan at low interest to the individual enterpriser/investor that enhances the overall investment in energy-intensive sectors such as heavy machinery, automobiles, and other electronic applications that minimizing the environmental excellence (Usman and Jahanger. 2021; Yang et al., 2021b; 2020). In the recent literature, some researchers have examined the influences of the remittance inflow on environmental performance for different regions. Usman and Jahanger. (2021) examined the links among remittances inflow, institutional quality, and ecological footprint and reported that remittances inflow and institutional quality increase the environmental degradation. Likewise, Yang et al., (2020) inspected the nexus between remittances inflow, globalization, and environmental pollution in 97 global countries from 1990-2016. Their empirical evidence indicated that remittance inflows significantly enhance environmental decay while globalization has a favorable effect on environmental sustainability. Similarly, Yang et al., (2021) studies the influence of remittances inflow on environmental pollution proxied with ecological footprint and reported that remittances inflow is a positive association with environmental degradation. Furthermore, Jiang et al., (2021); Ahmad et al., (2019); Neog et al., (2020); Khan et al., (2020); Villanthenkodath et al., (2020); Qingquan, et al., (2020); Brown et al., (2020) have documented that remittances inflow positively influences the environmental degradation. Whereas the a negative association between remittances inflow and environmental quality in the context of different regions (Opoku et al., 2021; Sharma et al., 2019).

\section{2-Renewable-non-renewable energy utilization-environment nexus}

Considering the dynamic nexus between renewable and non-renewable energy consumption and the environment, Shahnazi and Shabani (2021) applied the classical econometrics method during the time period from 2000 to 2017 in the case of European countries. Their outcomes indicated that renewable energy had a negative effect on environmental degradation while economic freedom exerted a U-shaped effect on environmental decay. Similarly, Azam et al., (2021) analyzed the association among renewable energy, nuclear energy, and environmental degradation in the top ten polluted countries based on Fully Modified Ordinary Least Squares (FMOLS) techniques from 19902014.Their empirical results indicated that renewable and nuclear energy utilization leads to significant circumstances to clean energy production. Likewise, Usman et al., (2020c) probed the causal association among financial development, renewable and non-renewable energy utilization, and ecological footprint in the top fifteen highest emitting countries covering the period from 1990 to 2017 . The results indicated that financial development and renewable 
energy utilization help to reduce environmental decay. Anwar et al., (2021) inspected the dynamic linkages among renewable and non-renewable energy utilization and $\mathrm{CO}_{2}$ emission in the case of Asian countries and found that renewable energy consumption leads to a decrease in environmental degradation. Khan et al., (2021) studied the association among natural resources, renewable energy, non-renewable energy utilization, and environmental sustainability using the generalized method of moments (GMM) approach from 1971 to 2016. The results of the study indicated that natural resources and renewable energy utilization improves environmental sustainability while non-renewable energy utilization worsens environmental quality. Moreover, Nathaniel et al., (2021) examined the link of economic growth, natural resources, human capital, renewable energy utilization on environmental sustainability in the case of BRICS countries. The empirical results indicated that economic growth and natural resources increase the ecological footprint while renewable energy utilization decreases the ecological footprint. In the same vein, Pata and Caglar (2021) documented that a negative association between renewable energy and environmental sustainability.

\section{2-Foreign direct investment-economic growth-environment nexus}

Several recent studies have examined the association between FDI and environmental degradation. For instance, Opoku et al., (2021) reported that FDI increases environmental pollution These findings also support the pollution halo hypothesis. Bulut et al., (2021) examined the link of GDP and FDI on the environmental degradation from 1970-2016 in the case of turkey. The empirical results of the paper show that both hypotheses i.e., the pollution haven hypothesis and EKC hypothesis are valid in Turkey. Some scholars also found the existence of pollution haven hypothesis, for instance, Assamoi, et al., (2020) for Cote d'Ivoire; Bulus and Koc (2021) for Korea; Solarin et al., (2017). for Ghana; Guzel and Okumus (2020) for five Asian Countries; Rana and Sharma (2019) for India; Nadeem et al., (2020) for India. Many other researchers also found inverted U-shaped EKC hypothesis such as Germani et al.,(2020) for Italian provinces, Farhani et al.,(2020) for three large economies (China, United State, India), Ullah and Khan,(2020) for Pakistan, Altıntaş and Kassouri,(2020) for 14 European countries, Chen and Taylor,(2020) for Singapore, Yilanci et al.,(2020) for 232 Chinese cities, Rahman,(2020) for top ten electricity consuming countries, Köksal et al.,(2020) for Turkey. Anser et al.,(2020) for G7 countries, Kongbuamai et al.,(2020) for eight ASEAN countries, Katircioglu et al.,(2020) for Cyprus.

\section{3-Data, model specification, and empirical methodology}




\subsection{Data}

In order to explore the effect of globalization, economic growth, renewable and nonrenewable energy utilization on the ecological footprint, a balanced panel data-set was applied for the top ten remittances-receiving countries (please see the geographical coverage of top ten remittances-receiving countries) India, Mexico, Philippines, France, Egypt, Nigeria, Pakistan, Bangladesh, China, Vietnam, Germany during the time period from 1990 to 2018. The ecological footprint (EFP) is measured as an aggregate of six inclusive indicators i.e., carbon footprint, build-up land, cropland, grazing land, fishing grounds, and forest land footprints concerning the global hectares per capita; the remittances inflow (RMT) is calculated in term of personal remittances, received (current US\$), the economic growth per capita (GDP) is measured in per capita constant 2010 US\$; the variable of foreign direct investment (FDI) is calculated net inflow (\% of GDP); the renewable energy utilization (RENV) is estimated in term of nuclear, wind, hydroelectricity and solar whereas the utilization of coal, oil, and natural gas is used as an indicator for non-renewable energy utilization ( NRENV). The data of RMT, GDP, FDI, RENV, and NRENV are acquired from World Development Indicators (WDI.2020). The data of EFP is taken from the Global Footprint Websites (GFPN.2020). All the variable descriptions and data sources are presented in Table.1.

Table 1. Variable description and data sources

\begin{tabular}{llll}
\hline Variables & \multicolumn{1}{c}{ Description } & Unit of measurement & Data sources \\
\hline EFP & Ecological footprint & per capita global hectares & GFPN, (2020) \\
REM & Remittances Inflow & Personal remittances, received (current US\$) & WDI, (2020) \\
GDP & Economic growth & Constant 2010 US\$ in per capita & WDI, (2020) \\
FDI & Foreign direct investment & Foreign direct investment, net inflow (\% of GDP) & WDI, (2020) \\
REC & Renewable energy use & $\%$ of total final energy use & WDI, (2020) \\
NRENV & Non-renewable energy use & Fossil fuel energy consumption (\% of total) & WDI, (2020)
\end{tabular}

Note: GFPN stands for Global Footprint Network, WDI stands for world development Indicators. 


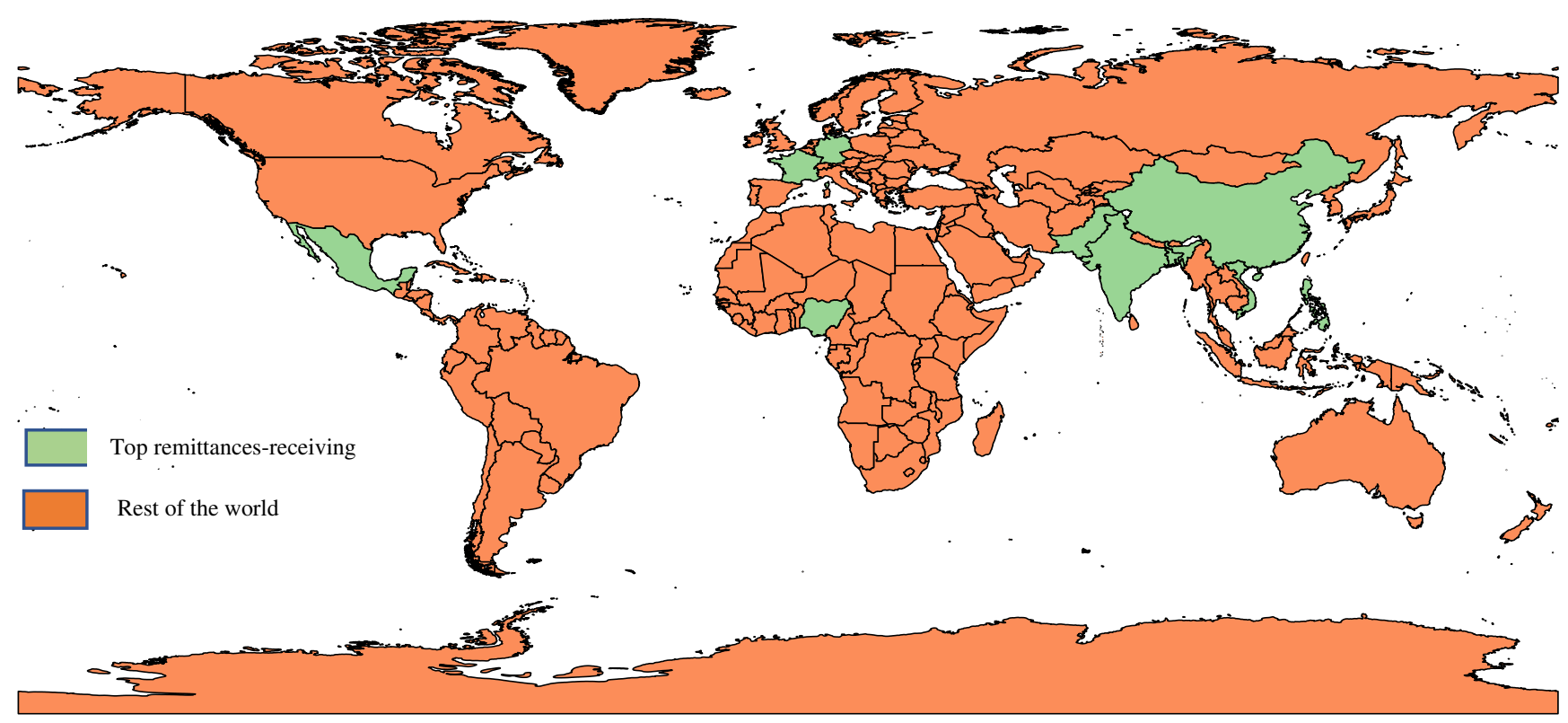

Figure 1: Geographical Coverage of Top Health Expenditure Countries

\subsection{Model specification}

This study builds on the literature of (Yang et al.,2021a; 2020b; 2020; Usman and Jahanger (2021); Usman et al., (2020c) by integrating remittances inflow, economic growth, renewable and non-renewable energy utilization. In order to minimize the likelihood of data sharpness and heteroscedasticity of all variables data-set of this study is transformed into the natural logarithm. For this purpose, the panel version of the econometric model is presented as follows:

$$
\mathrm{EFP}_{\mathrm{it}}=\mathrm{f}\left(\mathrm{RMT}_{\mathrm{it}}, \mathrm{GDP}_{\mathrm{it}}, \mathrm{FDI}_{\mathrm{it}}, \mathrm{REC}_{\mathrm{it}}, \mathrm{NRENV}_{\mathrm{it}}\right)
$$

Log transformation of Eq.1 is signified in Eq. 2 as follows:

$$
\begin{aligned}
\ln \left(\mathrm{EFP}_{\mathrm{it}}\right)=\beta_{0} & +\beta_{1 \mathrm{i}} \ln \left(\mathrm{RMT}_{\mathrm{it}}\right)+\beta_{2 \mathrm{i}} \ln \left(\mathrm{GDP}_{\mathrm{it}}\right)+\beta_{3 \mathrm{i}} \ln \left(\mathrm{FDI}_{\mathrm{it}}\right)+\beta_{4 \mathrm{i}} \ln \left(\mathrm{REC}_{\mathrm{it}}\right) \\
& +\beta_{5 \mathrm{i}} \ln \left(\mathrm{NRENV}_{\mathrm{it}}\right)+\varepsilon_{\mathrm{it}}
\end{aligned}
$$

Additionally, this study adds an economic growth square (GDPS) to verify the validity of the Environmental Kuznets Curve (EKC) hypothesis. The extended form of the EKC hypothesis can be expressed as follows:

$$
\begin{aligned}
\ln \left(\mathrm{EFP}_{\mathrm{it}}\right)=\beta_{0} & +\beta_{1 \mathrm{i}} \ln \left(\mathrm{RMT}_{\mathrm{it}}\right)+\beta_{2 \mathrm{i}} \ln \left(\mathrm{GDP}_{\mathrm{it}}\right)+\beta_{3 \mathrm{i}} \ln \left(\mathrm{GDPS}_{\mathrm{it}}\right) \\
& +\beta_{4 \mathrm{i}} \ln \left(\mathrm{FDI}_{\mathrm{it}}\right)+\beta_{5 \mathrm{i}} \ln \left(\mathrm{REC}_{\mathrm{it}}\right)+\beta_{6 \mathrm{i}} \ln \left(\mathrm{NRENV}_{\mathrm{it}}\right)+\varepsilon_{\mathrm{it}}
\end{aligned}
$$

Where $\boldsymbol{i}, \boldsymbol{t}$ and $\varepsilon_{\mathrm{it}}$ indicate the cross-sections, time periods, and stochastic error terms. $\beta_{0}$ denotes the constant term, $\varepsilon_{\text {it }}$ displays the error term and $\beta 1, \beta 2, \beta 3, \beta 4, \beta 5, \beta 6$ 
represents the elasticity of concern variables. Furthermore, the predictable sign of RMT is unclear, for instance, Yang et al., (2021b; 2020) defined an adverse impact of remittances inflow on environmental sustainability. On contrarily, other empirical published literature i.e., Opoku et al., (2021); Sharma et al., (2019) found that remittances inflow have a positive influence on environmental degradation. As a result, the predictable co-efficient sign of remittances inflow on environmental sustainability may be either positive/negative. The study expects an adverse coefficient sign for REC due to the positive attractiveness of REC in minimizing environmental degradation. On the other hand, the impact of GDP and NREC on environmental pollution is predictable to be positive such as (Ullah and Khan,2020; Altıntaş and Kassouri, 2020; Chen and Taylor, 2020; Yang et al., 2021b; Usman et al., 2020c).

Table 2: Correlation Metric

\begin{tabular}{ccccccccc}
\hline & LnEF & LnRMT & LnGDP & LnFDI & LnRENV & LnNRENV & VIF & $1 /$ VIF \\
\hline LnEF & 1 & & & & & & ----- & ---- \\
LnRMT & $0.3458^{*}$ & 1 & & & & & 1.25 & 0.800695 \\
LnGDP & $0.8360^{*}$ & $0.3907 *$ & 1 & & & & 2.38 & 0.420657 \\
LnFDI & $0.3709^{*}$ & $0.1821^{*}$ & $0.2024^{*}$ & 1 & & & 1.06 & 0.944996 \\
LnRENV & $-0.8973^{*}$ & $-0.2452^{*}$ & $-0.7244^{*}$ & $-0.1515^{*}$ & 1 & & 2.74 & 0.365219 \\
LnNRENV & $0.5335^{*}$ & $0.2847^{*}$ & $0.4196^{*}$ & 0.0768 & $-0.5937^{*}$ & 1 & 1.61 & 0.621888 \\
\hline
\end{tabular}

Note: $* * *, * * *$ shows the coefficients are significant at the 1\%,5\%,10\% level of significance, respectively.

VIF stands for Variance Inflation Factor. Mean VIF value is 1.81

The correction metrics among concerned variables after natural logarithm is expressed in table.2. A highly positive association (0.8360) exists between ecological footprint and economic growth per capita, while a highly negative $(0.8973)$ is observed between renewable energy utilization and ecological footprint. The descriptive statistics of our variables are expressed in Table.3 from 1990 to 2018 through box plots (see Fig.2)

Table 3. Descriptive Statistics

\begin{tabular}{cccccc}
\hline Variable & Obs & Mean & Std. Dev. & Min & Max \\
\hline LnEF & 290 & -.1770874 & .4860609 & -1.2439 & 0.6521 \\
LnGDP & 290 & 11.70009 & .6515317 & 10.4692 & 13.0363 \\
LnRMT & 290 & 9.821923 & .5803523 & 7.0003 & 10.8964 \\
LnFDI & 290 & .1562931 & .5144368 & -2.3476 & 1.1059
\end{tabular}




\begin{tabular}{cccccc} 
LnRENV & 290 & 1.436474 & .3893489 & 0.2985 & 1.9485 \\
LnNRENV & 290 & 1.75786 & .1878189 & 1.2001 & 1.9591 \\
\hline
\end{tabular}

Note: Min and Max show the minimum and maximum value of all variables; Std. Dev indicate the standard deviation
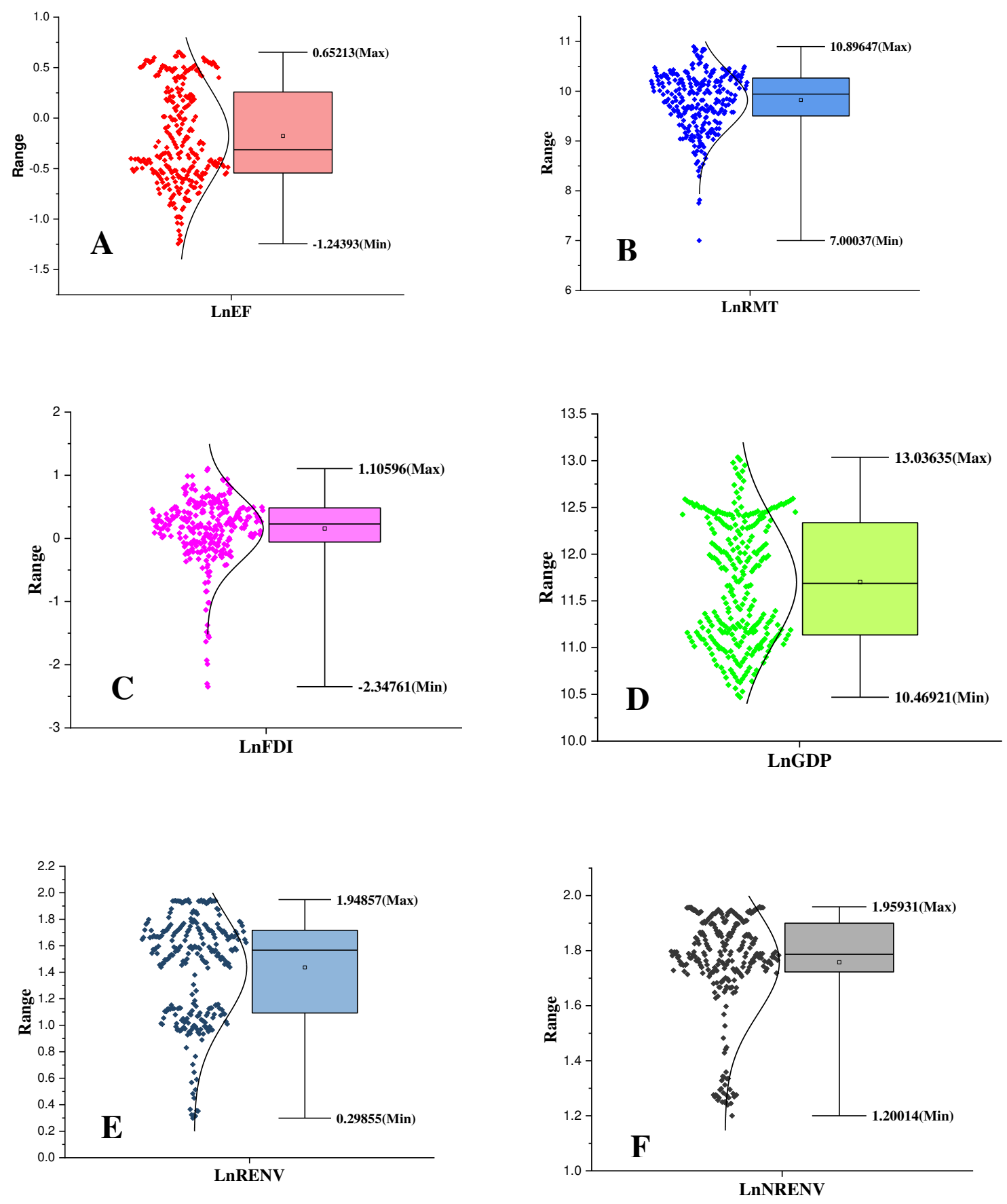

Figure 2: Box-plot summery descriptive statistics of our key variables. (A) LnEFP (B) LnRMT (C) LnFDI (D) LnGDP (E) LnRENV (F) LnNRENV

\subsection{Methodological framework}


Firstly, this study proceeds with the examination of cross-sectional dependency (CSD) estimators as a consequence to address the issue of panel data valuation and assure that the empirical analysis is efficient, reliable, and unbiased. Figure 3 represents illustrations of the road map of econometric techniques of the current study. First, we use four CSD estimators recommended by Pesaran (2004) are employed for this purpose with Eqs.4 \&5 stated as follows:

$$
\begin{gathered}
\mathrm{CSD}=\sqrt{\frac{2 \mathrm{Q}}{\mathrm{N}(\mathrm{N}-1)}}\left(\sum_{i=1}^{N-1} \sum_{j=i+1}^{N} \hat{\theta}_{i j}\right) \sim \mathrm{N}(0,1) i, j \\
\mathrm{CSD}=1,2,3 \ldots \ldots \ldots \ldots . . .70 \ldots \ldots . . \mathrm{N} \\
\mathrm{R}=\sqrt{\frac{2 \mathrm{Q}}{\mathrm{N}(\mathrm{N}-1)}\left(\sum_{i=1}^{N-1} \sum_{j=i+1}^{N} \hat{\theta}_{i j}\right) \frac{(\mathrm{Q}-\mathrm{h}) \hat{\theta}_{i j}^{2}-\mathrm{F}(\mathrm{Q}-\mathrm{h}) \hat{\theta}_{i j}^{2}}{\operatorname{Var}(\mathrm{Q}-\mathrm{h}) \hat{\theta}_{i j}^{2}}}
\end{gathered}
$$

Where $\mathrm{N}$ represents the panel (cross-sectional dimensions) and Q represents the sample size (time durations) of the study. After verifying the CSD within the panel data-set, more consolidation will be proceeding to implement the second-generation estimator. The secondgeneration estimator tests have gained attention in the environment economic literature. Therefore, this study employs second-generation stationary tests such as cross-sectional augmented IPS (CIPS) and cross-sectional augmented ADF (CADF) estimators to examine the stationary properties of the concerned variables. Pesaran (2007) proposed the CADF stationary test is expressed in Eq.6 is specified as follows:

$\Delta Y_{i t}=\beta_{i}+\beta_{i} y_{i, t-1}+\gamma_{i} \bar{y}_{t-1}+\varphi_{i} \Delta \bar{y}_{t}+\varepsilon_{\mathrm{it}}$

Where $\Delta$ denotes the difference operator, $Y_{i t}$ represents the concerned variables, $\beta$ is an individual intercept and $\varepsilon_{\text {it }}$ show the country-specific effects. Schwarz information criterion (SIC) approach concludes the lag dimension. The null hypothesis $\left(\mathrm{H}_{0}\right)$ for both estimators (CIPS, CADF) is that all individuals are not unit-root within time-series panel dataset and the alternative hypothesis $\left(\mathrm{H}_{1}\right)$ is that all individuals are not unit-root within a time series panel dataset. After estimation the integration order $(0,1)$ of candidate variables, it is necessary to test the long-run elasticity among concerned variables. Therefore, Westerlund (2007) anticipated 
the second-generation cointegration estimator which handles the issue of CSD and slope heterogeneity. Westerlund long-run elasticity test is expressed in Eq.7 as follows:

$$
\Delta Y_{i t}=\rho_{i}^{\prime} d_{t}+\sigma_{i}\left(Y_{i t-1}-\alpha_{i}^{\prime} x_{i t-1}\right)+\sum_{j=1}^{m_{i}} \sigma_{i j} \Delta y_{i t-j}+\sum_{j=-m_{i}}^{m_{i}} \omega_{i j} \Delta x_{i, t-j}+\varepsilon_{i t}
$$

Where $\sigma_{\mathrm{i}}$ denotes the speed of modification that adjusts the system back to long-run stability. But error correction based Westerlund long-run elasticity contains different approaches such as (i.e., $\mathrm{G}_{\mathrm{t}}, \mathrm{G}_{\mathrm{a}}, \mathrm{P}_{\mathrm{t}}$, and $\mathrm{P}_{\mathrm{a}}$ ) is anticipated by Eq. 8 \& 9 represented as follows:

$$
\begin{aligned}
& \mathrm{G}_{\tau}=\frac{1}{\mathrm{~N}} \sum_{i=1}^{N} \frac{\mathrm{v}_{\mathrm{i}}}{\mathrm{KF}\left(\mathrm{v}_{\mathrm{i}}\right)} \\
& \mathrm{G}_{\mathrm{a}}=\frac{1}{\mathrm{~N}} \sum_{i=1}^{N} \frac{\mathrm{Qv}_{\mathrm{i}}}{\mathrm{v}_{\mathrm{i}}^{\prime}(1)}
\end{aligned}
$$

And panel cointegration tests statistics $\left(\mathrm{P}_{\mathrm{t}}\right.$ and $\left.\mathrm{P}_{\mathrm{a}}\right)$ is deliberated by the Eqs. 10 and 11 as follows:

$$
\begin{aligned}
& \mathrm{P}_{\tau}=\frac{\hat{\mathrm{U}}_{\mathrm{i}}}{\mathrm{KF}\left(\hat{\mathrm{U}}_{\mathrm{i}}\right)} \\
& \mathrm{P}_{\mathrm{a}}=Q \hat{\mathrm{U}}
\end{aligned}
$$

After substantiating the long-run elasticity among concern variables, the assessment of long-run parameters is projected through Continuously Updated Fully Modified (CUP-FM) and Continuously Updated Bias-Corrected (CUP-BC) approach proposed by Bai et al. (2009); Bai and Kao (2006). were employed to inspect the impact of concerted variables considering CSD by following Eq.12 as follows:

$$
y_{i t}=\varpi_{i}+\delta x_{i t}+\varepsilon_{i t}
$$

$$
x_{i t}=x_{i, t-1}+\mu_{i t} \quad \varepsilon_{i t}=\xi_{i} l_{t}+\pi_{i t}
$$

Where $\xi_{i}$ and $l_{t}$ are factor loading and unobserved factors 1(0) correspondingly, $x$ denotes concerned variables. Fully modified ordinary least square (FM-OLS) approach to detect the presence of factors (Phillips and Hansen, 1990) as is given in Eq.13 as follow: 


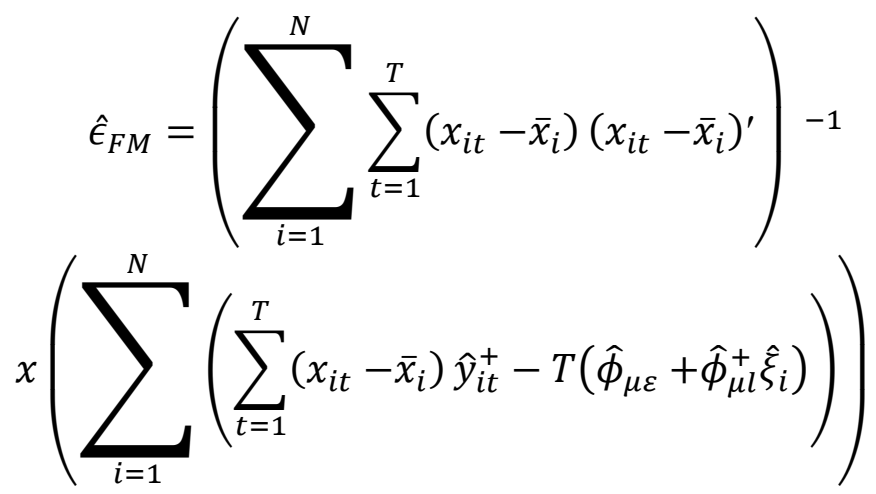

$\epsilon$ projected by FMOLS are imitated using residuals from the FMOLS of the existing period since convergence happens. This process is called the CUP-FM approach is expressed in Eq.14 as follow:

$$
\begin{aligned}
& y_{i t}=\varpi_{i}+\delta x_{i t}+\xi_{i} l_{t}+\varepsilon_{i t} \\
& x_{i t}=x_{i, t-1}+\mu_{i t} \quad l_{t}=l_{t-1}+\pi_{t}
\end{aligned}
$$

Where $l_{t}$ are pragmatic or unpragmatic I (1) time series called Stochastic and deterministic trends. It is supposed that the independent variable (remittances inflow) $\left(x_{i t}\right)$ are independent across $\mathrm{i}$. The final step of the econometric approach is to investigate the causality association among candidates' variables. So, this current study used Dumitrescu and Hurlin (2012) estimator that deals with the CSD and heterogeneity that may occur in the model. The mathematical explanation of the Dumitrescu and Hurlin (D-H) non-causality test is expressed in Eq. 15 as follows:

$$
X_{i t}=\tau_{i}+\sum_{j-1}^{J} \eta_{i}^{j} X_{i(t-j)}+\sum_{j-1}^{J} \epsilon_{i}^{j} Z_{i(t-j)}+\varepsilon_{i t}
$$

Where $\mathrm{X}$ and $\mathrm{Z}$ denote the expected observables; the term $\eta_{i}^{j}$ and $\epsilon_{i}^{j}$ show the OLS and AR estimators. $\mathrm{i}$ indicate the cross-sections. The approach presents two tests (W bar-statistics and $\mathrm{Z}$ bar-statistics) from which outcomes are shown bidirectional causality, unidirectional causality, and no causality association among the variables. 


$$
P_{N \cdot Q}^{H N C}=\mathrm{N}^{-1} \sum_{i=1}^{N} \mathrm{U}_{\mathrm{i}, \mathrm{Q}}
$$

$\mathrm{U}_{\mathrm{i}, \mathrm{Q}}$ denotes the Wald statistics of each cross-section (countries). $\mathrm{H}_{0}$ (null) and $\mathrm{H}_{1}$ (alternative) hypothesis of D.H causality are stated in Eqs: 17 and 18 as follows:

$$
\begin{aligned}
& \mathrm{H}_{0}: \lambda_{i}=0 \quad \text { for } \forall i \\
& \mathrm{H}_{1}:\left\{\begin{array}{lll}
\lambda_{i}=0 & \text { for all } & i=1,2,3, \ldots \ldots \ldots \ldots \ldots, \mathrm{N}_{1} \\
\lambda_{i} \neq 0 & \text { for all } & i=\mathrm{N}_{1}+1,2,3, \ldots \ldots \ldots N
\end{array}\right\}
\end{aligned}
$$

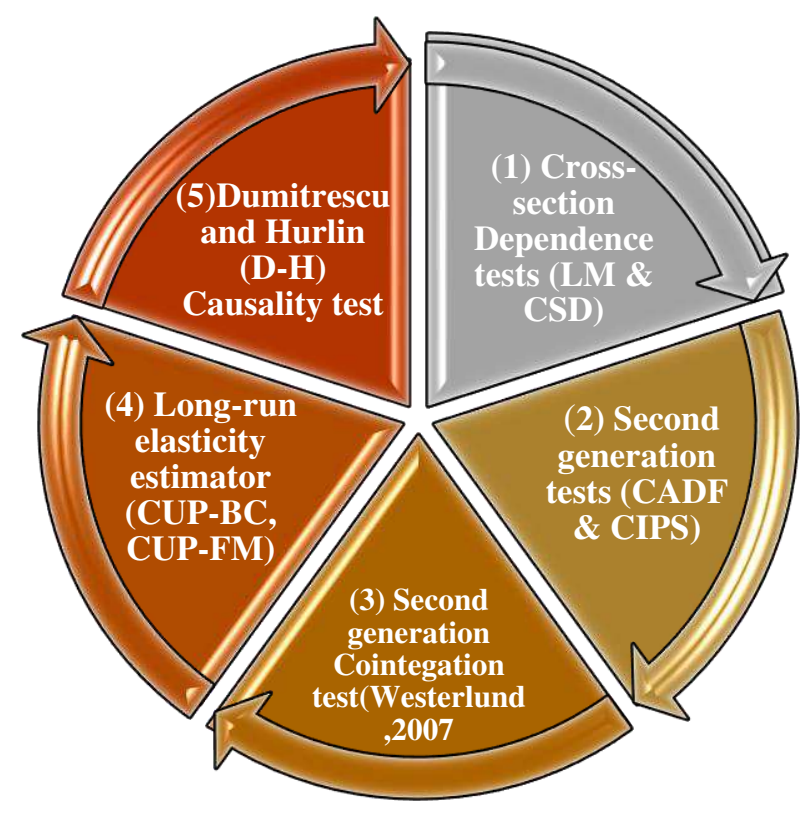

Fig. 3. Road map of econometric modeling strategy

\section{Results and discussion:}

\subsection{Cross-sectional dependence (CSD) test results:}

Before proceeding to examine the unit root properties of the concern variables, we check the occurrence of Cross-sectional dependence (CSD) in the panel dataset. In this regard, we have applied four CSD methods such as: (1) Breusch-Pagan LM, (2) Pesaran Scaled LM, (3) Bias-corrected scaled LM, and (4) Pesaran CSD and empirical outcomes are stated in Table.4. These empirical outcomes disclose that the null hypothesis of no CSD is rejected, in doing so implying the presence of CSD in the panel. More peculiarly, all the variables (i.e., 
LnEFP, LnRMT, LnFDI, LnGDP, LnRENV and LnNRENV) are statistically significant at a $1 \%$ significance level.

Table-4: Cross-sectional dependence analysis

\begin{tabular}{|c|c|c|c|c|c|c|c|c|}
\hline \multirow{2}{*}{$\begin{array}{l}\text { Series } \\
\text { Ln EP }\end{array}$} & \multicolumn{2}{|c|}{ Breusch-Pagan LM } & \multicolumn{2}{|c|}{ Pesaran scaled LM } & \multicolumn{2}{|c|}{ Bias-corrected scaled LM } & \multicolumn{2}{|c|}{ Pesaran CD } \\
\hline & $521.168 * * *$ & 0.000 & $50.192 * * *$ & 0.000 & $50.013 * * *$ & 0.000 & $6.851 * * *$ & 0.000 \\
\hline LnRMt & $1042.153 * * *$ & 0.000 & $105.109 * * *$ & 0.000 & $104.930 * * *$ & 0.000 & $32.179 * *$ & 0.000 \\
\hline LFDI & $126.489 * * *$ & 0.000 & $8.589 * * *$ & 0.000 & $8.411 * * *$ & 0.000 & $6.243 * * *$ & 0.000 \\
\hline LnGDP & $1259.983 * * *$ & 0.000 & $128.070 * * *$ & 0.000 & $127.891 * * *$ & 0.000 & $35.492 * * *$ & 0.000 \\
\hline LnNRENV & $851.206 * * *$ & 0.000 & $84.981 * * *$ & 0.000 & $84.803 * * *$ & 0.000 & $3.875^{* * *}$ & 0.000 \\
\hline LnRENV & $702.412 * * *$ & 0.000 & $69.297 * * *$ & 0.000 & $69.118 * * *$ & 0.000 & $5.524 * * *$ & 0.000 \\
\hline
\end{tabular}

Note: $* * *$ shows the significance level at $1 \%$.

\subsection{Results of panel stationary tests}

After verifying the CSD of data, the next stage of the empirical examining is to check the integration order/stationary level of all said variables. The first-generation stationary tests can show to be ambiguous, as these tests ignore the presence of CSD. Therefore, to address the CSD problem, we applied second-generation stationary tests namely: CADF and CIPS, and the findings are expressed in Table.5. The empirical outcomes describe that some said variables (LnEFP, LnRMT, LnFDI, LnGDP, LnRENV, and LnNRENV) have a stationary issue at level but after the shift of first difference, I(1) all said variables become stationary. This displays the best explanation to test the long-run cointegration whether it occurs or not.

Table 5: Results of Panel stationary Tests

\begin{tabular}{lllll}
\hline \multirow{2}{*}{ Series } & \multicolumn{3}{c}{ CIPS } & \multicolumn{1}{c}{ CADF } \\
\cline { 2 - 5 } & At Level & $1^{\text {st }}$ difference & At Level & $1^{\text {st }}$ difference \\
\hline LnEF & -1.204 & $-4.523^{* * *}$ & -1.365 & $-3.451^{* * *}$ \\
LnGDP & -1.815 & $-3.012^{* * *}$ & -2.036 & $-2.403 * *$ \\
LnGDPS & -1.891 & $-3.046^{* * *}$ & -2.107 & $-2.465^{* *}$ \\
LnRMT & $-2.503^{* * *}$ & $-4.674^{* * *}$ & $-2.301 * *$ & $-3.321 * * *$ \\
LnFDI & $-2.319^{* *}$ & $-5.285^{* * *}$ & -1.967 & $-4.293^{* * *}$ \\
LnRENV & $-3.432 * * *$ & $-5.435^{* * *}$ & $-2.263 * *$ & $-3.244 * * *$
\end{tabular}


Note: $* * *$ denotes $1 \%$ and $* *$ denotes $5 \%$ level of significance, respectively.

\subsection{Results of panel cointegration tests}

After verifying the order of integration lever among the said variables, we apply the Westerlund (2007) cointegration test to examine the long-run equilibrium among said variables in the presence of CSD. The outcomes of Westerlund cointegration tests are described in Table. 6 and we note that the null hypothesis $\left(\mathrm{H}_{0}\right)$ of no cointegration is rejected at the $1 \%$ and 5\% levels of significance. This confirms that the variables LnEFP, LnRMT, LnFDI, LnGDP, LnRENV, and LnNRENV contain long-run cointegration over the period from 1990 to 2018 in the top ten remittances-receiving countries.

Table 6: Panel Westerlund cointegration tests results

\begin{tabular}{lcccc}
\hline Statistics & $\mathrm{G}_{\tau}$ & $\mathrm{G}_{\mathrm{a}}$ & $\mathrm{P}_{\tau}$ & $\mathrm{P}_{\mathrm{a}}$ \\
\hline Values & $-2.301 * *$ & $-11.701 * * *$ & $-13.974 * *$ & $-10.710^{*}$ \\
Z-values & -1.446 & -0.541 & -3.987 & 0.351 \\
P-values & 0.093 & 0.280 & 0.000 & 0.740 \\
Robust P-values & 0.017 & 0.070 & 0.029 & 0.001 \\
\hline
\end{tabular}

Note: $* * * * * \& *$ indicate significance level at $1 \%, 5 \%$ and $10 \%$

\subsection{Results of long-run elasticity estimates}

To further explore the long-run elasticity among said variables such as LnEFP, LnRMT, LnFDI, LnGDP, LnRENV, and LnNRENV variables in the cointegration association of each panel using the Continuously Updated Fully Modified (CUP_FM) and Continuously Updated Bias-Corrected (CUP_BC). The results of the CUP_FM test are stated in Table.7. The outcome demonstration that remittances inflow (RMT) has a positive and significant effect on environmental degradation. More specifically, a $1 \%$ increase in RMT will lead to an increase in the environmental decay by $0.028 \%$ at a $1 \%$ level of significance. RMT degradation the environmental quality because it might likely enhance industrial production and aggregate consumption expenditure. The industries sector will use more energy for more economic growth, particularly fossil fuels and thus causing more environmental degradation in the top remittances-receiving countries. This outcome is similar to those found by (Yang et al.,2021b; 
2020; Usman and Jahanger, 2021). Besides, the findings of economic growth (GDP) have a positive and significant effect on environmental pollution, while the economic growth square (GDPS) is negative, which strongly supports the invested U-shaped Environmental Kuznets Curve (EKC) hypothesis. It is noted a 1\% enhance in GDP will lead to an increase in the environmental decay by $0.036 \%$, while a $1 \%$ enhance in GDPS will lead to minimizing environmental degradation by $0.013 \%$. This finding of this study is consistent with some earlier studies of Yilanci et al.,(2020); Rahman,(2020); Köksal et al.,(2020); Anser et al.,(2020); Kongbuamai et al.,(2020); Katircioglu et al.,(2020).

Regarding the coefficient of foreign direct investment (FDI), it has a significant positive on environmental pollution in top remittances-receiving countries. More particularly, a $1 \%$ escalation in FDI will lead to an increase in the environmental decay by $0.03 \%$ level of significance. These findings also support the "pollution haven hypothesis". The positive longrun of influence FDI on environmental degradation approves the fear of the challenges of free flow of trade openness and foreign investment flows. Multinational firms (Heavy or polluted industries) move from developed to developing countries through FDI because these countries environmental regulation is less strict and weak. (Yang et al.,2020). According to the World Bank, the contribution of top remittances-receiving countries to foreign direct investment net inflow increases from 140522354434.27US\$ in 1990 to 1126434818564.98 US\$ in 2019 its mean $12.47 \%$ increases FDI within twenty-nine years (WDI.2020b). These results coincide with the findings of Assamoi, et al., (2020); Bulus and Koc (2021); Solarin et al., (2017); Guzel and Okumus (2020); Rana and Sharma (2019); Nadeem et al., (2020). Furthermore, the outcome of renewable energy utilization (RENV) has a statistically significant and negative influence on environmental degradation in top remittances-receiving countries. A $1 \%$ increase in RENV leads to a decrease the environmental pollution by $0.011 \%$. These results are in line with the finding of Usman et al., (2020c). RENV decreases environmental degradation in top remittances countries as renewable energy generation is dictated by hydroelectricity. Hydroelectricity is a pollution-free (clean) source of energy because it does not include the burning of dirty fossil fuels. The elasticity of non-renewable energy utilization (NRENV) is statistically significant and positive, indicating that a $1 \%$ increase in NRENV is linked with a $0.005 \%$ rise in environmental degradation. The conventional source of energy utilization (coal, oil, petroleum, natural gas, and electricity) causes environmental decay as energy is produced from fossil fuel and it is usually pragmatic that fuel fuels create waste material, mercury, and 
emission which degradation the environmental quality. This finding is similar to those found by Yang et al.; (2021a); Usman et al., (2020a; 2020c).

Table-7: Result of Long run elasticity estimates

\begin{tabular}{ccc}
\hline Variables & CUP_FM & CUP_ $_{-}$BC \\
\hline LnRMT & $0.028^{* * *}$ & $0.066^{* * *}$ \\
& $(2.748)$ & $(4.137)$ \\
LnGDP & $0.036 * * *$ & 0.007 \\
& $(6.406)$ & $(1.305)$ \\
LnGDPS & $-0.013 * * *$ & $-0.004 * * *$ \\
& $(18.426)$ & $(6.307)$ \\
LnFDI & $0.03 * * *$ & $0.025 * * *$ \\
& $(3.913)$ & $(3.72)$ \\
LnRENV & $-0.011 * * *$ & -0.003 \\
& $(-2.843)$ & $(-1.327)$ \\
LnNRENV & $0.005^{*}$ & 0.006 \\
& $(1.721)$ & $(1.55)$ \\
\hline
\end{tabular}

Note: t-statistics are within parentheses $* * *, * *, *$ significant value at $1 \%, 5 \%, 10 \%$ level.

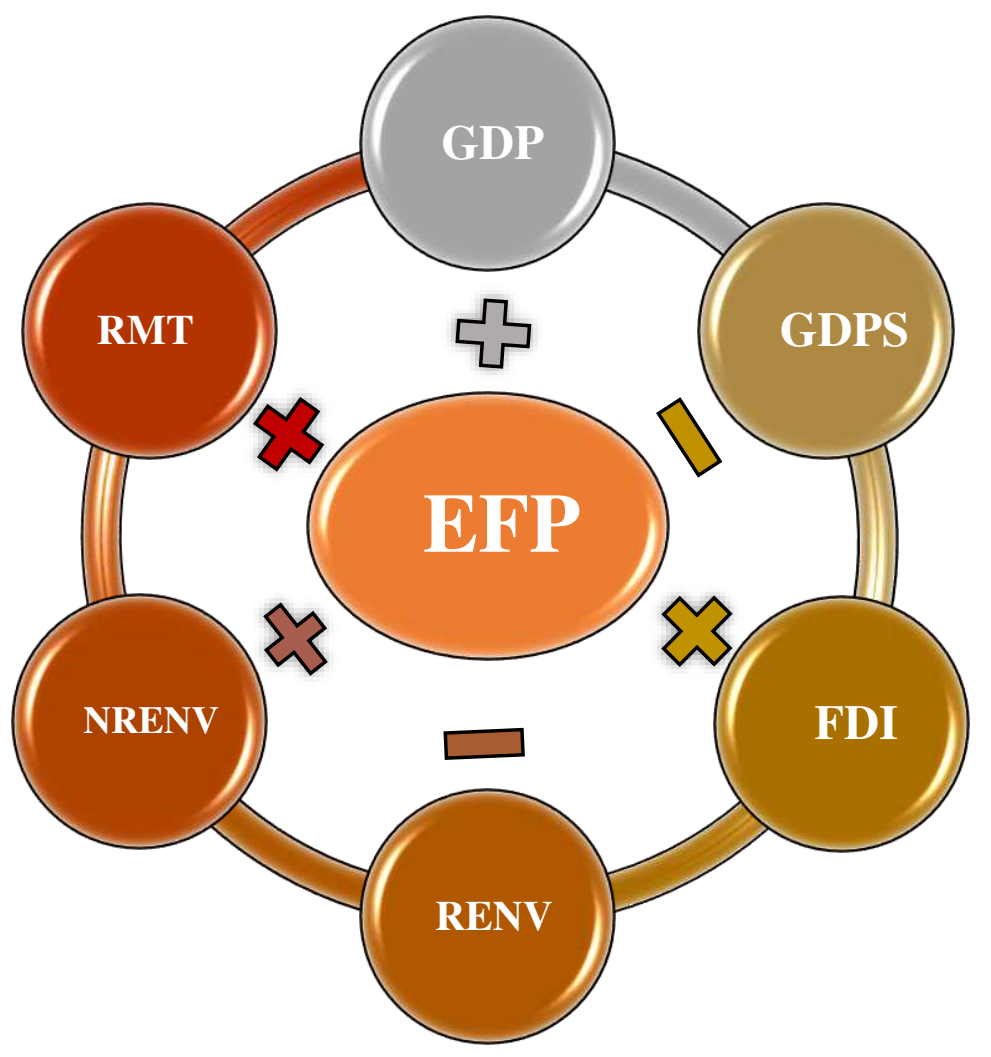

Fig. 3: Graphical appearance of empirical results 


\subsection{Outcomes of country-wise long-run elasticity evaluations}

The long-run panel data examination is before reflected in the existing portion of this study. However, the dynamic links between globalization, economic growth, renewable and non-renewable energy utilization, foreign direct investment, and ecological footprint for country-wise are curious. Furthermore, this study discovers the long-run elasticity of the EFP for the time series data of each top ten remittances-receiving countries. The fully modified ordinary least square (FMOLS) approach (Pedroni 2001) is applied for the estimation of longrun country-wise analysis and results are reported in Table.8. The outcome shows that RMT has a positive impact on environmental degradation in some remittance-receiving countries. Particularly, $1 \%$ enhance in RMT will enlarge the environmental pollution in case of China, France, Germany, India, Mexico, Pakistan with $1.2127 \%, 1.5465 \%, 0.0093 \%, 0.3503 \%$, $0.0675 \%, 0.9773 \%, 0.0078 \%$ respectively. In general, the inflow of remittances enhances aggregate demand for the production process. And due to less regulations about the environment in these countries, more requests for industrial production goods will raise the utilization of fossil fuels which degradation the environmental quality. These outcomes are contradicted with the previously published literature, i.e., Jiang et al., (2021); Ahmad et al., (2019); Neog et al., (2020); Khan et al., (2020); Villanthenkodath et al., (2020); Qingquan, et al., (2020); Brown et al., (2020). On the other hand, RMT has a negative influence on environmental degradation in some remittances-receiving countries such as Bangladesh and Nigeria. A $1 \%$ increase in RMT leads to a decrease in environmental pollution in the case of Bangladesh and Nigeria by $0.0184 \%$ and $0.3006 \%$ respectively. These results of RMT are congruent to the outcomes of Opoku et al., (2021); Sharma et al., (2019).

Furthermore, the inverted U-shaped Environmental Kuznets Curve (EKC) hypothesis was confirmed only in the six countries out of ten, such as Bangladesh, China, France, India, Pakistan, and Vietnam at $1 \%$ and $5 \%$ significance levels, respectively. The findings are parallel to Anser et al.,(2020); Kongbuamai et al.,(2020); Katircioglu et al.,(2020). However, Germany, Mexico, and Nigeria have a U-shaped association between ecological footprint and economic development at a $1 \%$ and $5 \%$ level of significance. The conclusions are akin to Apergis et al., (2017); Apergis and Payne (2009). Moreover, the EKC hypothesis does not hold in the case of the Philippines. This result is consistent with the outcomes of Pata \& Aydin. (2020). Additionally, the "Pollution Haven Hypothesis" was verified in the case of Bangladesh, Mexico, Nigeria, Pakistan, and the Philippines countries. These results coincide with the findings of Guzel and Okumus (2020); Rana and Sharma (2019); Nadeem et al., (2020). 
Table 7. Results of country-wise long-run estimations (FMOLS results)

\begin{tabular}{|c|c|c|c|c|c|c|c|c|c|c|c|c|}
\hline \multirow[b]{2}{*}{ Series } & \multicolumn{2}{|c|}{ LNRMT } & \multicolumn{2}{|c|}{ LNGDP } & \multicolumn{2}{|c|}{ LGDPS } & \multicolumn{2}{|c|}{ LNFDI } & \multicolumn{2}{|c|}{ LNNRENV } & \multicolumn{2}{|c|}{ LNRENV } \\
\hline & Coeff. & Prob. & Coeff. & Prob. & Coeff. & Prob. & Coeff. & Prob. & Coeff. & Prob. & Coeff. & Prob. \\
\hline Bangladesh & -0.0184 & 0.8628 & $0.3185^{* * * *}$ & 0.0000 & $-2.1033^{*} *$ & 0.0004 & $0.2269 * * *$ & 0.0000 & 0.0146 & 0.6314 & $-0.8144 * * *$ & 0.0000 \\
\hline China & $1.2127 * *$ & 0.0001 & $0.2601 * * *$ & 0.0000 & $-3.3155^{* * *}$ & 0.0000 & 0.0028 & 0.7390 & 0.0065 & 0.2035 & $-0.6486^{* * *}$ & 0.0000 \\
\hline France & $1.5465^{* * *}$ & 0.0000 & $0.7581 * *$ & 0.0139 & $-1.3103^{* *}$ & 0.0042 & -0.0139 & 0.2247 & 0.0203 & 0.5380 & $-0.1732 * *$ & 0.0079 \\
\hline Germany & 0.0093 & 0.9901 & $-1.1398 * *$ & 0.0007 & $0.4989 * *$ & 0.0015 & 0.0083 & 0.2464 & $0.0892 * *$ & 0.0183 & -0.0773 & 0.2085 \\
\hline India & 0.3503 & 0.1476 & $0.2303^{* * *}$ & 0.0000 & $-1.3749 * *$ & 0.0091 & 0.0028 & 0.6112 & 0.0067 & 0.7180 & $-1.1900 * * *$ & 0.0000 \\
\hline Mexico & $0.0675^{* * *}$ & 0.0000 & $-0.8841^{* *}$ & 0.0002 & $0.9411 * *$ & 0.0172 & $0.1057 * *$ & 0.0030 & $-0.1171 * *$ & 0.0143 & $0.4965^{* *}$ & 0.0180 \\
\hline Nigeria & $-0.3006^{* * *}$ & 0.0000 & $-3.9957 * * *$ & 0.0000 & $0.9967 * * *$ & 0.0000 & $0.1112^{* *}$ & 0.0184 & $0.6812 * * *$ & 0.0000 & $-0.3296 * * *$ & 0.0000 \\
\hline Pakistan & 0.9773 & 0.1795 & $0.6490 * *$ & 0.0001 & $-0.2137 * *$ & 0.0003 & $0.0633 * *$ & 0.0001 & 0.0091 & 0.7318 & 0.1111 & 0.7813 \\
\hline Philippines & 0.0078 & 0.3988 & 0.5482 & 0.2826 & -0.8350 & 0.7259 & $0.0381 * *$ & 0.0784 & $-0.4644^{*}$ & 0.0953 & -0.0129 & 0.1265 \\
\hline Vietnam & $-0.2350^{*}$ & 0.0778 & $0.8552 * * *$ & 0.0000 & $-0.3423 * * *$ & 0.0001 & -0.0069 & 0.8318 & -0.0062 & 0.7893 & $-1.2119 * * *$ & 0.0000 \\
\hline
\end{tabular}

Note: $* * *, * *$ and $*$ indicate significance level at $1 \%, 5 \%$, and $10 \%$ 
Furthermore, the coefficient of non-renewable energy utilization (NNRENV) has a positive and significant impact on environmental degradation in the case of Germany and Nigeria countries. Specifically, a $1 \%$ increase in NNRENV will lead to an increasing environmental decay in the case of Germany and Nigeria by $0.0892 \%$ and $0.6812 \%$ respectively. This finding is alike to those found by Yang et al.; (2021a); Usman et al., (2020a; 2020c). Besides, NNRENV demonstrated the negative influence on the environmental decay in the case of Mexico depicting that a $1 \%$ increase in NNRENV will lead to a decrease the environmental pollution by $0.1171 \%$ in the long term and these outcomes are consistent with the existing published literature of Rahman et al., (2019). Renewable energy utilization (RENV) has a negative influence on the environment in TOP remittances-receiving countries. Particularly, $1 \%$ enlargement in RENV will enhance the environmental quality in case of Bangladesh, China, France, India, Nigeria and Vietnam with $0.8144 \%, 0.6486 \%, 0.1732 \%, 1.1900 \%$, $0.3296 \%$ and $1.2119 \%$ respectively. These results coincide with the findings of Usman et al., (2020c).

For, robustness checks, this study performed an alternative method i.e., Continuously Updated Bias-Corrected (CUP-BC). Table 6 also the conclusions of the regressions analysis by engaging the CUP-BC. In sum, the results of this technique are consistent with the of the CUP- FM approach as reported in table 6.

\subsection{Outcomes of panel Dumitrescu and Hurlin (D-H) pairwise non-causality test}

Lastly, the final step of the econometric process of empirical analysis is to determine the causality association among said variables i.e., globalization, economic growth, renewable, and non-renewable energy utilization, and ecological footprint. We discover causal association within the panel Dumitrescu and Hurlin (D-H) context which can tickle the problem of CSD. Table 8 demonstrations that a feedback hypothesis is revealed between EFP and GDP, between EFP and GDPS, between EFP and FDI, between EFP and RENV, between RMT and GDP, between FDI and GDP, between RENV and GDP, between RENV and NRENV, between RENV and RMT, between NRENV and RMT. In contrast, a growth hypothesis is discovered from EFP to RMT, from GDP to GDPS, from GDP to RENV, from GDP to RENV, from RMT to GDP, from FDI to GDP, from FDI to RMT. However, our empirical findings are consistent with some previous studies (Usman et al., 2020c; Usman and Jahanger. 2021; Khan et al., 2020) in the case of different panel economies. Table. 8 and Figure. 4 will offer significant support to policymakers for implementing efficient strategies to control pollution levels for the topremittances countries in the future. 
Table. 8: Dumitrescu Hurlin Panel Causality

\begin{tabular}{|c|c|c|c|c|c|c|c|}
\hline Variables & LnEFP & LnGDP & LnGDPS & LnRMT & LnFDI & LnRENV & LnNRENV \\
\hline \multirow[t]{3}{*}{ LnEFP } & & $4.3360 * * *$ & $4.3640 * * *$ & $2.3847 * * *$ & $2.7114 * * *$ & $5.4781 * * *$ & $2.8865 * * *$ \\
\hline & - & $(7.4595)$ & $(7.5222)$ & (3.0964) & $(3.8267)$ & $(10.0134)$ & $(4.2183)$ \\
\hline & & 0.0000 & 0.0000 & 0.0020 & 0.0001 & 0.0000 & 0.0000 \\
\hline \multirow[t]{3}{*}{ LnGDP } & 1.6379 & & $3.3160 * * *$ & 1.4985 & 0.6699 & $3.9161 * * *$ & $3.3325 * * *$ \\
\hline & (1.4264) & - & $(5.1787)$ & $(1.1146)$ & $(-0.7381)$ & (6.5207) & $(5.2157)$ \\
\hline & 0.1537 & & 0.0000 & 0.2650 & 0.4604 & 0.0000 & 0.0000 \\
\hline \multirow[t]{3}{*}{ LnGDPS } & 1.6124 & $3.2481 * * *$ & & 1.4979 & 0.6611 & $3.8030 * * *$ & $3.2751 * * *$ \\
\hline & (1.3693) & (5.0269) & - & (1.1134) & $(-0.7579)$ & $(6.2677)$ & $(5.0872)$ \\
\hline & 0.1709 & 0.0000 & & 0.2655 & 0.4485 & 0.0000 & 0.0000 \\
\hline \multirow[t]{3}{*}{ LnRMT } & $3.7439 * * *$ & $4.7876^{* * *}$ & $4.7927 * * *$ & & 1.4464 & $2.6109 * * *$ & $3.7951 * * *$ \\
\hline & $(6.1355)$ & $(8.4693)$ & $(8.4807)$ & - & $(0.9982)$ & $(3.6021)$ & $(6.2501)$ \\
\hline & 0.0000 & 0.0000 & 0.0000 & & 0.3182 & 0.0003 & 0.0000 \\
\hline \multirow[t]{3}{*}{ LnFDI } & 1.5242 & $2.0565^{* *}$ & $2.0698 * *$ & $2.1221 * *$ & & $1.8393 *$ & $3.0691 * * *$ \\
\hline & $(1.1721)$ & $(2.3624)$ & $(2.3922)$ & $(2.5091)$ & - & $(1.8768)$ & $(4.6266)$ \\
\hline & 0.2412 & 0.0182 & 0.0167 & 0.0121 & & 0.0605 & 0.0000 \\
\hline \multirow[t]{3}{*}{ LnRENV } & 0.9228 & $9.0414 * * *$ & $9.0984 * * *$ & $20.2250 * * *$ & 1.6359 & & $22.7153^{* * * *}$ \\
\hline & $(-0.1727)$ & $(17.9812)$ & (18.1086) & $(42.9885)$ & $(1.4220)$ & - & $(48.5569)$ \\
\hline & 0.8629 & 0.0000 & 0.0000 & 0.0271 & 0.1550 & & 0.0000 \\
\hline \multirow[t]{3}{*}{ LnNRENV } & 1.5249 & $2.4969 * * *$ & $2.5159 * * *$ & $4.3074 * * *$ & 1.1588 & 3.1016 *** & \\
\hline & $(1.1738)$ & (3.3471) & (3.3897) & $(7.3956)$ & $(0.3550)$ & $(4.6993)$ & - \\
\hline & 0.2405 & 0.0008 & 0.0007 & 0.0000 & 0.7226 & 0.0000 & \\
\hline
\end{tabular}

Note: Top values indicate $\mathrm{w}$-stat. ( ) shows z-stats. ${ }^{* * *}$ denotes $1 \%$, $* *$ denotes $5 \%$, and $*$ denotes $10 \%$ level of significance, respectively.

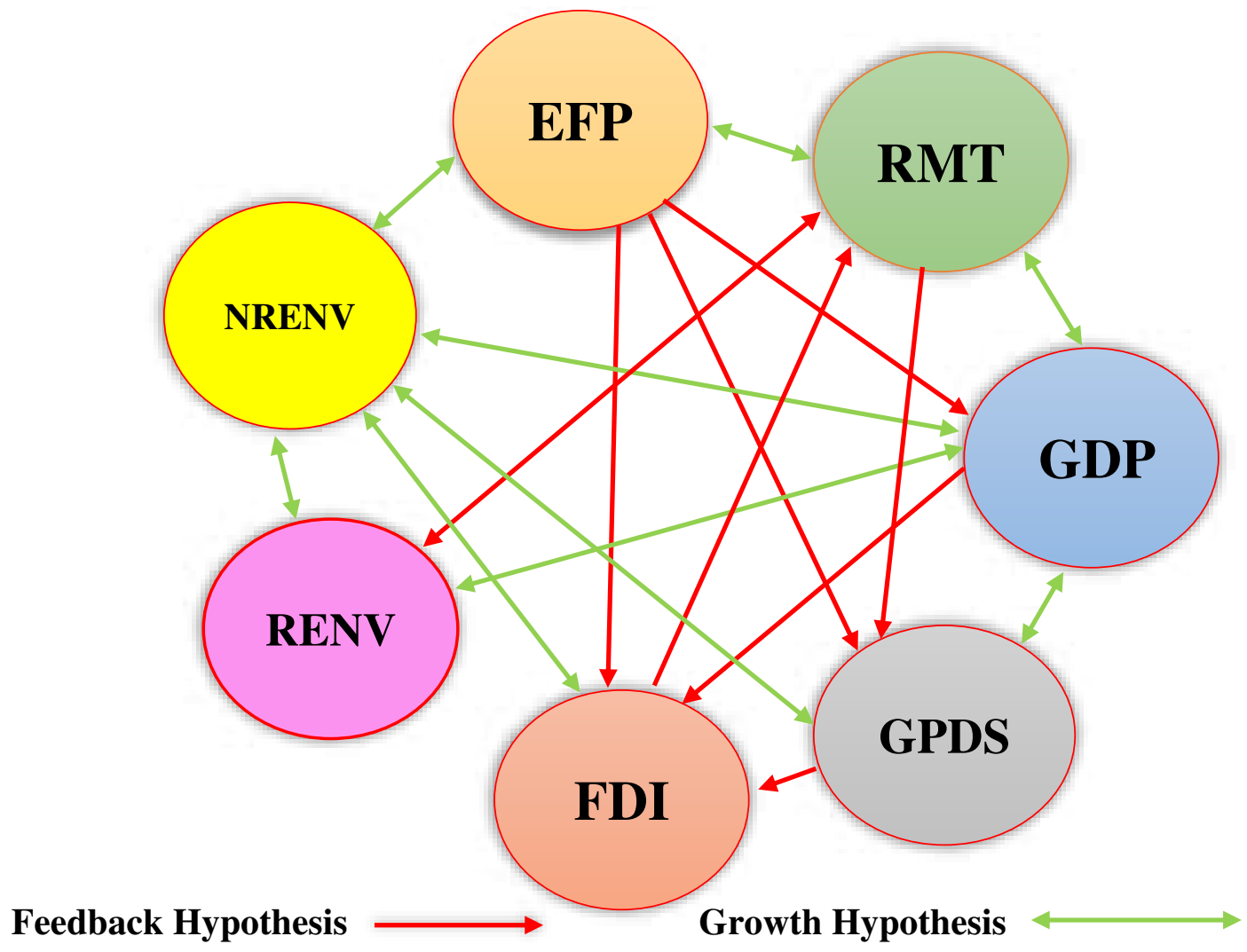

Figure.4. Causality association for top remittances countries 


\section{Conclusion and Policy Implication:}

This study examines the relationship between globalization, economic growth, renewable and non-renewable energy utilization, foreign direct investment, and ecological footprint for the top remittances-receiving countries using panel data from 1990 to 2018. This study applies second-generation techniques to test the associations among the concern variables. We apply four Cross-Sectional dependence (CSD) techniques to investigates the CSD among the said variables. From a stationarity point of view, this study using CIPS and CADF approach of panel unit root tests and Westerlund's (2007) panel ECM applied to check the long-run equilibrium among the variables. The long-run cointegration relationship was investigated through the Continuously Updated Fully Modified (CUP-FM) and Continuously Updated Bias-Corrected (CUP-BC) method. For country-wise long-relationship explored through FMOLS approach. Dumitrescu-Hurlin panel causality test applies to verify the casual association among the said variables.

The findings of CUP-BC and CUP-FM techniques show that remittance inflow and non-renewable energy utilization and foreign direct investment boost environmental degradation which proves the existence of the pollution haven hypothesis while renewable energy utilization significantly reduces environmental pollution. Moreover, the empirical results confirm the validity of the inverted U-shaped Environmental Kuznets Curve (EKC) hypothesis in the case of top remittances countries. More precisely, for country-wise analysis FMOLS approach results indicates that remittances inflow has a positive on environmental degradation in the case of China, France, Germany, India, Mexico, Pakistan but negatively influence in case of Bangladesh and Nigeria economies. Besides we examine the country-wise EKC hypothesis and stimulatingly, our findings confirm the evidence of the invested U-shaped EKC hypothesis in the case of Bangladesh, China, France, India, Pakistan, and Vietnam economies, while a U-shaped EKC hypothesis found in the case of Germany, Mexico and Nigeria economies. Moreover, the EKC hypothesis does not hold in the case of the Philippines. Moreover, the "Pollution Haven Hypothesis" was verified in the case of Bangladesh, Mexico, Nigeria, Pakistan, and the Philippines economies. Furthermore, the outcome of panel D-H causality test demonstration that a between ecological footprint and economic growth, between ecological footprint and economic growth square, between ecological footprint and foreign direct investment, between ecological footprint and renewable energy utilization, between remittance inflow and ecological footprint, between foreign direct investment and ecological 
footprint, between renewable energy utilization and economic growth, between renewable and non-renewable energy utilization, between renewable energy utilization and remittances inflow, between non-renewable energy utilization and remittances inflow.

Our findings have useful policy implications for governments, policymakers, and academicians. First, it is understood that, beyond the role played in terms of financial/ economic progress and in term of subsidy support for households, the remittances inflow is an influential tool permitting affecting the environmental sustainability depending on how they owed. Government should address the adverse influence of remittances inflow on environmental sustainability by putting restrictions on polluting industries through strict financial regulation and imperative to evade structural bureaucracy problem in order to simplify received remittances in a formal way. Besides, the government minimizing the remittances costs and given more subsidies to enhance remittances inflow to these top remittances-receiving countries remains an appropriate goal under sustainable development. Second, foreign direct investment degradation the environmental quality so policymakers should attach these investors that bring eco-friendly technologies to reduce the level of emission and achieve a cleaner environment. Government should explore zero-carbon technology that led to minimize environmental degradation and also need to modification the excellence of trade intensity from upper to lower carbon industry/manufacture through extensive stages for research and development $(R \& D)$ and eco-friendly industries. Third, since renewable energy may also help to improve environmental quality so we recommended to the policymakers should enhance the role of renewable energy utilizing in reducing the environmental degradation arising from the consumption (oil, fuel, coal) of energy, most of which comes from fossil fuels.

This study has some limitations which can be pointed out in future research works. Since we do not consider the important variables such as social, economic, and cultural variables along with remittances flows and variance decomposition analysis (VDA) that is useful to examine the future contribution of concerned variables towards environmental degradation with a large time dimension.

\section{Ethics declarations}

Ethics approval and consent to participate: Not applicable

Consent for publication: Not applicable

Competing interests: The authors declare that they have no competing interests 
Funding: This research did not receive any specific grant from funding agencies in the public, commercial, or not-for-profit sectors.

Authors' contributions: Conceptualization, AJ. methodology and software, AJ, formal analysis, AJ., data collection., AJ, writing-original draft preparation, AJ., LZ and BJ., writingreview and editing., BY, LZ, and AJ., supervision, BY \& LZ project administration., AJ. All authors have read and approved the manuscript.

Availability of data and materials: The datasets used and/or analyzed during the current study are variability from the corresponding author on reasonable request

\section{Reference:}

Ahmad, M., Ul Haq, Z., Khan, Z., Khattak, S. I., Rahman, Z. U., \& Khan, S. (2019). Does the inflow of remittances cause environmental degradation? Empirical evidence from China. Economic research-Ekonomska istraživanja,32(1), 2099-2121. https://doi.org/10.1080/1331677X.2019.1642783

Altıntaş, H., \& Kassouri, Y. (2020). Is the environmental Kuznets Curve in Europe related to the per-capita ecological footprint or $\mathrm{CO} 2$ emissions ?. Ecological Indicators, 113, 106187. https://doi.org/10.1016/j.ecolind.2020.106187

Anser, M. K., Yousaf, Z., Nassani, A. A., Abro, M. M. Q., \& Zaman, K. (2020). International tourism, social distribution, and environmental Kuznets curve: evidence from a panel of G-7 countries. Environmental Science and Pollution Research.

https://doi.org/10.1007/s11356-019-07196-2. https://doi.org/10.1007/s11356-020$\underline{07956-5}$

Anwar, A., Siddique, M., Dogan, E., \& Sharif, A. (2021). The moderating role of renewable and non-renewable energy in environment-income nexus for ASEAN countries: Evidence from Method of Moments Quantile Regression. Renewable Energy, 164, 956-967. https://doi.org/10.1016/j.renene.2020.09.128

Apergis N, Christou C, Gupta R (2017). Are there environmental Kuznets curves for US statelevel CO2 emissions? Renew Sust Energ Rev 69:551-558. https://doi.org/10.1016/j.rser.2016.11.219

Apergis N, Payne JE (2009) CO2 emissions, energy usage, and output in Central America. Energy Policy 37(8):3282-3286. https://doi.org/10.1016/j.enpol.2009.03.048

Assamoi, G. R., Wang, S., Liu, Y., \& Gnangoin, Y. T. B. (2020). Investigating the pollution haven hypothesis in Cote d'Ivoire: evidence from autoregressive distributed lag (ARDL) approach with structural breaks. Environmental Science and Pollution Research, 1-14. https://doi.org/10.1007/s11356-020-08246-w

Azam, A., Rafiq, M., Shafique, M., Zhang, H., \& Yuan, J. (2021). Analyzing the effect of natural gas, nuclear energy and renewable energy on GDP and carbon emissions: A multi-variate panel data analysis. Energy, 219, 119592. ttps://doi.org/10.1016/j.energy.2020.119592

Bai, J., Kao, C., \& Ng, S. (2009). Panel cointegration with global stochastic trends. Journal of Econometrics, 149(1), 82-99. https://doi.org/10.1016/j.jeconom.2008.10.012 
Bai, J., Kao, C., (2006). On the Estimation and Inference of a Panel Cointegration Model with Cross-Sectional Dependence. Contrib. to Econ. Anal. 274, 3-30. https://doi.org/10.1016/S0573-8555(06)74001-9

Balsalobre-Lorente, D., Gokmenoglu, K. K., Taspinar, N., \& Cantos-Cantos, J. M. (2019). An approach to the pollution haven and pollution halo hypotheses in MINT countries. Environmental Science and Pollution Research,26(22), 23010-23026. https://doi.org/10.1007/s11356-019-05446-X

British Petroleum, (2019). BP statistical review of world energy, 68th edition 2019. Access at: https://www.bp.com/en/global/corporate/energy-economics/statistical-review-ofworld-energy.html

Brown, L., McFarlane, A., Campbell, K., \& Das, A. (2020). Remittances and CO2 emissions in Jamaica: an asymmetric modified environmental Kuznets curve. The Journal of Economic Asymmetries, 22, e00166. https://doi.org/10.1016/j.jeca.2020.e00166

Bulus, G. C., \& Koc, S. (2021). The effects of FDI and government expenditures on environmental pollution in Korea: the pollution haven hypothesis revisited. Environmental Science and Pollution Research, 1-16. https://doi.org/10.1007/s11356-021-13462-z

Bulut, U., Ucler, G., \& Inglesi-Lotz, R. (2021). Does the pollution haven hypothesis prevail in Turkey? Empirical evidence from nonlinear smooth transition models. Environmental Science and Pollution Research, 1-10. https://doi.org/10.1007/s11356-021-13476-7

Chen, Q., \& Taylor, D. (2020). Economic development and pollution emissions in Singapore: Evidence in support of the Environmental Kuznets Curve hypothesis and its implications for regional sustainability. Journal of Cleaner Production, 243, 118637. https://doi.org/10.1016/j.jclepro.2019.118637

De, P. K., \& Ratha, D. (2012). Impact of remittances on household income, asset and human capital: Evidence from Sri Lanka. Migration and Development, 1(1), 163-179. https://doi.org/10.1080/21632324.2012.719348

Dumitrescu, E.I., Hurlin, C., (2012). Testing for Granger non-causality in heterogeneous panels. Econ. Modell. 29, 1450e1460. https://doi.org/10.1016/j.econmod.2012.02.014 .

Essandoh, O. K., Islam, M., \& Kakinaka, M. (2020). Linking international trade and foreign direct investment to $\mathrm{CO} 2$ emissions: Any differences between developed and developing countries?. Science of the Total Environment, 712, 136437. https://doi.org/10.1016/j.scitotenv.2019.136437

Farhani, S., \& Balsalobre-Lorente, D. (2020). Comparing the role of coal to other energy resources in the environmental Kuznets curve of three large economies. The Chinese Economy, 53(1), 82-120. https://doi.org/10.1080/10971475.2019.1625519

GFPN. (2020). Global Footprint Network. (Accessed date 21-February -2020), https://www.footprintnetwork.org/our-work/ecological-footprint.

Grossman GM, Krueger AB (1991) Environmental impacts of a North American free trade agreement (No. w3914). National Bureau of Economic Research.

Guzel, A. E., \& Okumus, İ. (2020). Revisiting the pollution haven hypothesis in ASEAN-5 countries: new insights from panel data analysis. Environmental Science and Pollution Research, 27(15), 18157-18167. https://doi.org/10.1007/s11356-020-08317-y

IPCC, (2019) international Panel on Climate Change, Access at: https://www.ipcc.ch/site/assets/uploads/sites/2/2019/06/SR15_Full_Report_High_Res .pdf.

Jiang, Q., Khattak, S. I., Ahmad, M., \& Lin, P. (2021). Mitigation pathways to sustainable production and consumption: Examining the impact of commercial policy on carbon 
dioxide emissions in Australia. Sustainable Production and Consumption, 25, 390-403. https://doi.org/10.1016/i.spc.2020.11.016

Katircioglu, S., Saqib, N., Katircioglu, S., Kilinc, C. C., \& Gul, H. (2020). Estimating the effects of tourism growth on emission pollutants: empirical evidence from a small island, Cyprus. Air Quality, Atmosphere \& Health, 1-7. https://doi.org/10.1007/s11869-020-00803-z

Khan, I., Hou, F., \& Le, H. P. (2021). The impact of natural resources, energy consumption, and population growth on environmental quality: Fresh evidence from the United States of America. Science of the Total Environment, 754, 142222. https://doi.org/10.1016/j.scitotenv.2020.142222

Khan, Z. U., Ahmad, M., \& Khan, A. (2020). On the remittances-environment led hypothesis: empirical evidence from BRICS economies. Environmental Science and Pollution Research, 27(14), 16460-16471. https://doi.org/10.1007/s11356-020-07999-8

Köksal, C., Işik, M., \& Katircioğlu, S. (2020). The role of shadow economies in ecological footprint quality: empirical evidence from Turkey. Environmental Science and Pollution Research. https://doi.org/10.1007/s11356-020-07956-5

Kongbuamai, N., Bui, Q., Yousaf, H. M. A. U., \& Liu, Y. (2020). The impact of tourism and natural resources on the ecological footprint: a case study of ASEAN countries. Environmental Science and Pollution Research,27(16), 19251-19264. https://doi.org/10.1007/s11356-020-08582-x

Lv, Z., \& Li, S. (2021). How financial development affects CO2 emissions: a spatial econometric analysis. Journal of Environmental Management, 277, 111397. https://doi.org/10.1016/j.jenvman.2020.111397

Nadeem, A. M., Ali, T., Khan, M. T., \& Guo, Z. (2020). Relationship between inward FDI and environmental degradation for Pakistan: an exploration of pollution haven hypothesis through ARDL approach. Environmental Science and Pollution Research, 1-19. https://doi.org/10.1007/s11356-020-08083-X

Nathaniel, S. P., Yalçiner, K., \& Bekun, F. V. (2021). Assessing the environmental sustainability corridor: Linking natural resources, renewable energy, human capital, and ecological footprint in BRICS. Resources Policy, 70, 101924. https://doi.org/10.1016/i.resourpol.2020.101924

Nathaniel, S. P., Yalçiner, K., \& Bekun, F. V. (2021). Assessing the environmental sustainability corridor: Linking natural resources, renewable energy, human capital, and ecological footprint in BRICS. Resources Policy, 70, 101924. https://doi.org/10.1016/j.resourpol.2020.101924

Neog, Y., \& Yadava, A. K. (2020). Nexus among CO2 emissions, remittances, and financial development: a NARDL approach for India. Environmental Science and Pollution Research, 27(35), 44470-44481. https://doi.org/10.1007/s11356-020-10198-0

OECD, (2002). Foreign Direct Investment for Development: Maximising Benefits, Minimising Costs. Organisation for Economic Co-operation and Development. Access at: https://www.oecd.org/investment/investmentfordevelopment/foreigndirectinvestmentf ordevelopmentmaximisingbenefitsminimisingcosts.htm

Opoku, E. E. O., Adams, S., \& Aluko, O. A. (2021). The foreign direct investment-environment nexus: Does emission disaggregation matter?. Energy Reports, 7, 778-787. https://doi.org/10.1016/j.egyr.2021.01.035

Opoku, E. E. O., Adams, S., \& Aluko, O. A. (2021). The foreign direct investment-environment nexus: Does emission disaggregation matter?. Energy Reports, 7, 778-787. https://doi.org/10.1016/j.egyr.2021.01.035

Pata, U. K., \& Aydin, M. (2020). Testing the EKC hypothesis for the top six hydropower energy-consuming countries: evidence from Fourier Bootstrap ARDL procedure. Journal 
of Cleaner Production, 264, 121699. https://doi.org/10.1016/j.jclepro.2020.121699

Pata, U. K., \& Caglar, A. E. (2021). Investigating the EKC hypothesis with renewable energy consumption, human capital, globalization and trade openness for China: Evidence from augmented ARDL approach with a structural break. Energy, 216, 119220. https://doi.org/10.1016/j.energy.2020.119220

Pedroni, P., 2001. Purchasing power parity tests in cointegrated panels. Rev. Econ. Stat. https://doi.org/10.1162/003465301753237803

Pesaran, M.H., 2007. A simple panel unit root test in the presence of cross-section dependence.

J. Appl. Econom. https://doi.org/10.1002/jae.951

Phillips, P.C.B., Hansen, B.E., 1990. Statistical Inference in Instrumental Variables Regression with I(1) Processes. Rev. Econ. Stud. 57, 99. https://doi.org/10.2307/2297545

Qingquan, J., Khattak, S. I., Ahmad, M., \& Ping, L. (2020). A new approach to environmental sustainability: Assessing the impact of monetary policy on $\mathrm{CO} 2$ emissions in Asian economies. Sustainable Development, 28(5),

1331-1346. https://doi.org/10.1002/sd.2087

Rahman, M. M. (2020). Environmental degradation: The role of electricity consumption, economic growth and globalisation. Journal of environmental management, 253, 109742. https://doi.org/10.1016/j.jenvman.2019.109742

Rahman, Z.U., Cai, H., Ahmad, M., (2019). A new look at the remittances fdi-energyenvironment nexus in the case of selected asian nations. Singapore Econ Rev. https://doi.org/10.1142/S0217590819500176

Rana, R., \& Sharma, M. (2019). Dynamic causality testing for EKC hypothesis, pollution haven hypothesis and international trade in India. The Journal of International Trade \& Economic Development, 28(3), 348-364. https://doi.org/10.1080/09638199.2018.1542451

Safi, A., Chen, Y., Wahab, S., Ali, S., Yi, X., \& Imran, M. (2021). Financial instability and consumption-based carbon emission in E-7 countries: The role of trade and economic growth. Sustainable Production and Consumption, 27, 383-391. https://doi.org/10.1016/j.spc.2020.10.034

Shahnazi, R., \& Shabani, Z. D. (2021). The effects of renewable energy, spatial spillover of $\mathrm{CO} 2$ emissions and economic freedom on $\mathrm{CO} 2$ emissions in the EU. Renewable Energy, 169, 293-307. https://doi.org/10.1016/j.renene.2021.01.016

Sharma, K., Bhattarai, B., \& Ahmed, S. (2019). Aid, growth, remittances and carbon emissions in Nepal. The Energy Journal, 40(1). https://doi.org/10.5547/01956574.40.1.ksha

Shen, Y., Su, Z. W., Malik, M. Y., Umar, M., Khan, Z., \& Khan, M. (2021). Does green investment, financial development and natural resources rent limit carbon emissions? A provincial panel analysis of China. Science of The Total Environment, 755, 142538. https://doi.org/10.1016/j.scitotenv.2020.142538

Solarin, S. A., Al-Mulali, U., Musah, I., \& Ozturk, I. (2017). Investigating the pollution haven hypothesis in Ghana: an empirical investigation. Energy, 124, 706-719. https://doi.org/10.1016/j.energy.2017.02.089

Ullah, A., \& Khan, D. (2020). Testing environmental Kuznets curve hypothesis in the presence of green revolution: a cointegration analysis for Pakistan. Environmental Science and Pollution Research, 1-17. https://doi.org/10.1007/s11356-020-07648-0

UNDP (2015). the United Nations Development Programme report. Access at: https://www.un.org/en/ecosoc/about/mdg.shtml 
Usman, M., \& Jahanger, A. (2021). Heterogeneous effects of remittances and institutional quality in reducing environmental deficit in the presence of EKC hypothesis: A global study with the application of panel quantile regression. Environmental Science and Pollution Research, 1-19. https://doi.org/10.1007/s11356-021-13216-X

Usman, M., Kousar, R., \& Makhdum, M.S.A., (2020a). The role of financial development, tourism, and energy utilization in environmental deficit: evidence from 20 highest emitting economies. Environ. Sci. Pollut. Res. https://doi.org/10.1007/s11356-02010197-1

Usman, M., Kousar, R., Yaseen, M.R., \& Makhdum, M.S.A. (2020b). An empirical nexus between economic growth, energy utilization, trade policy, and ecological footprint: a continent-wise comparison in upper-middle-income countries. Environmental Science and Pollution Research, 27(31), 38995-39018. https://doi.org/10.1007/s11356-020$\underline{09772-31095}$

Usman, M., Makhdum, M, S, A., \& Kousar, R., (2020c). Does financial inclusion, renewable and non-renewable energy utilization accelerate ecological footprints and economic growth? Fresh evidence from 15 highest emitting countries. Sustainable Cities and Society, 65, 1098 102590. https://doi.org/10.1016/j.scs.2020.102590

Villanthenkodath, M. A., \& Mahalik, M. K. (2020). Technological innovation and environmental quality nexus in India: Does inward remittances matter?. Journal of Public Affairs, e2291. https://doi.org/10.1002/pa.2291

WDI. (2020). World Bank (World Development Indicators). (Accessed date 19-march-2021). https://databank.worldbank.org/indicator/NY.GDP.PCAP.CD/\%201ff4a498/\%20Popu lar- Indicators

WDI. (2020b). World Bank (World Development Indicators). (Accessed date 19-march-2021). https://data.worldbank.org/indicator/BX.KLT.DINV.CD.WD .

Westerlund, J. (2007). Testing for error correction in panel data. Oxford Bulletin of Economics and statistics, 69(6), 709-748. https://doi.org/10.1111/j.1468-0084.2007.00477.x.

Yang, B., Jahanger, A., \& Ali, M. (2021b). Remittances inflow affect the ecological footprint in BICS countries: do technological innovation and financial development matter?. Environmental Science and Pollution Research, 1-19. https://doi.org/10.1007/s11356021-12400-3 1134

Yang, B., Jahanger, A., \& Khan, M. A. (2020). Does the inflow of remittances and energy consumption increase CO 2 emissions in the era of globalization? A global perspective. Air Quality, Atmosphere \& Health, 13(11), 1313-1328. https://doi.org/10.1007/s11869-020-00885-9

Yang, B., Jahanger, A., Usman, M., \& Khan, M. A. (2021a). The dynamic linkage between globalization, financial development, energy utilization, and environmental sustainability in GCC countries. Environmental Science and Pollution Research, 11140 21. https://doi.org/10.1007/s11356-020-11576-4

Yilanci, V., \& Pata, U. K. (2020). Investigating the EKC hypothesis for China: the role of economic complexity on ecological footprint. Environmental Science and Pollution Research, 1-12. https://doi.org/10.1007/s11356-020-09434-4 
Figures

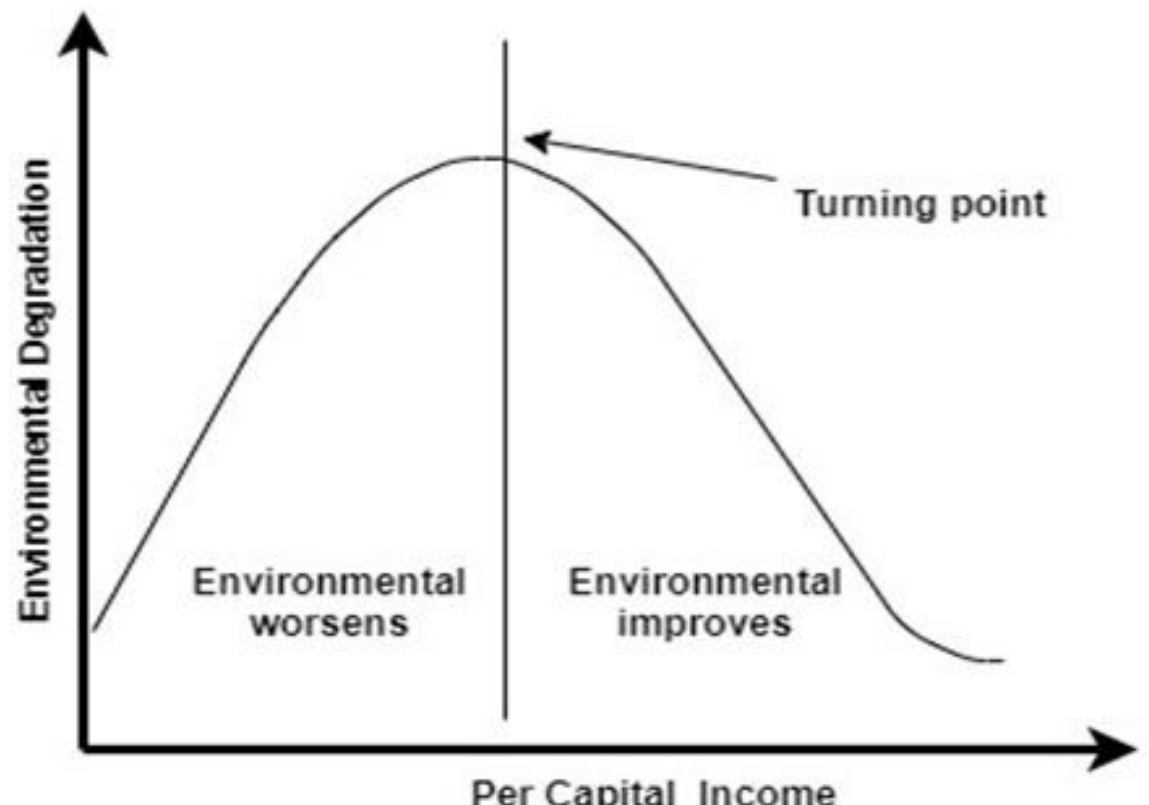

Figure 1

Environmental Kuznets Curve

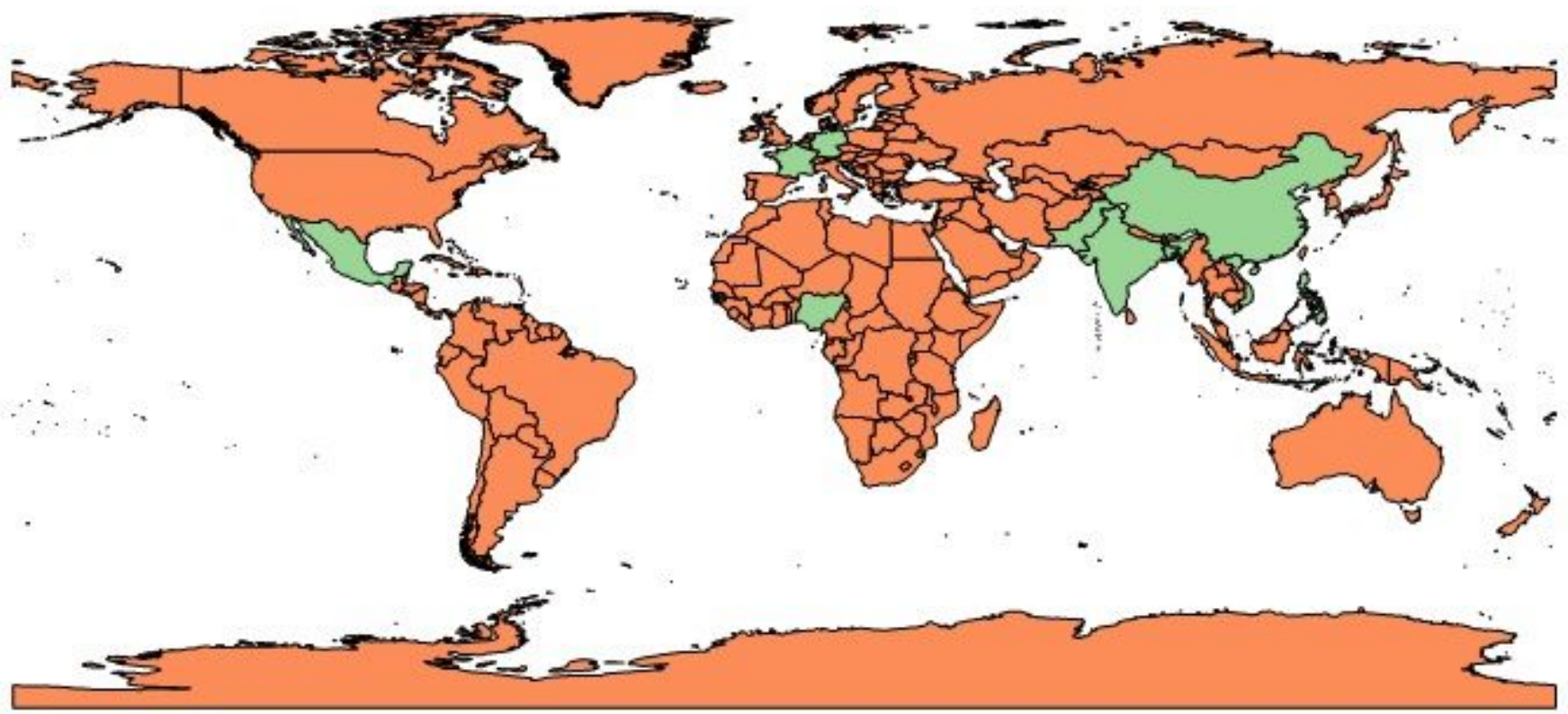

Figure 2

Geographical Coverage of Top Health Expenditure Countries. Note: The designations employed and the presentation of the material on this map do not imply the expression of any opinion whatsoever on the part of Research Square concerning the legal status of any country, territory, city or area or of its authorities, or concerning the delimitation of its frontiers or boundaries. This map has been provided by the authors. 

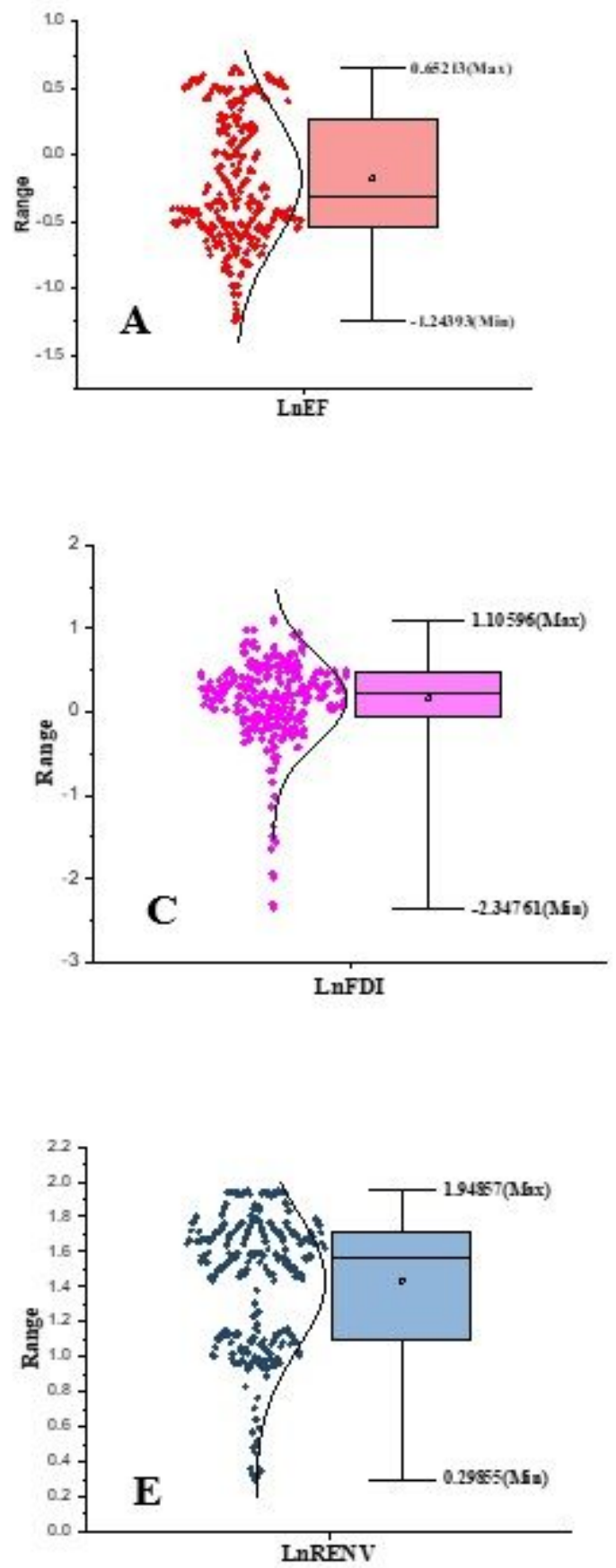
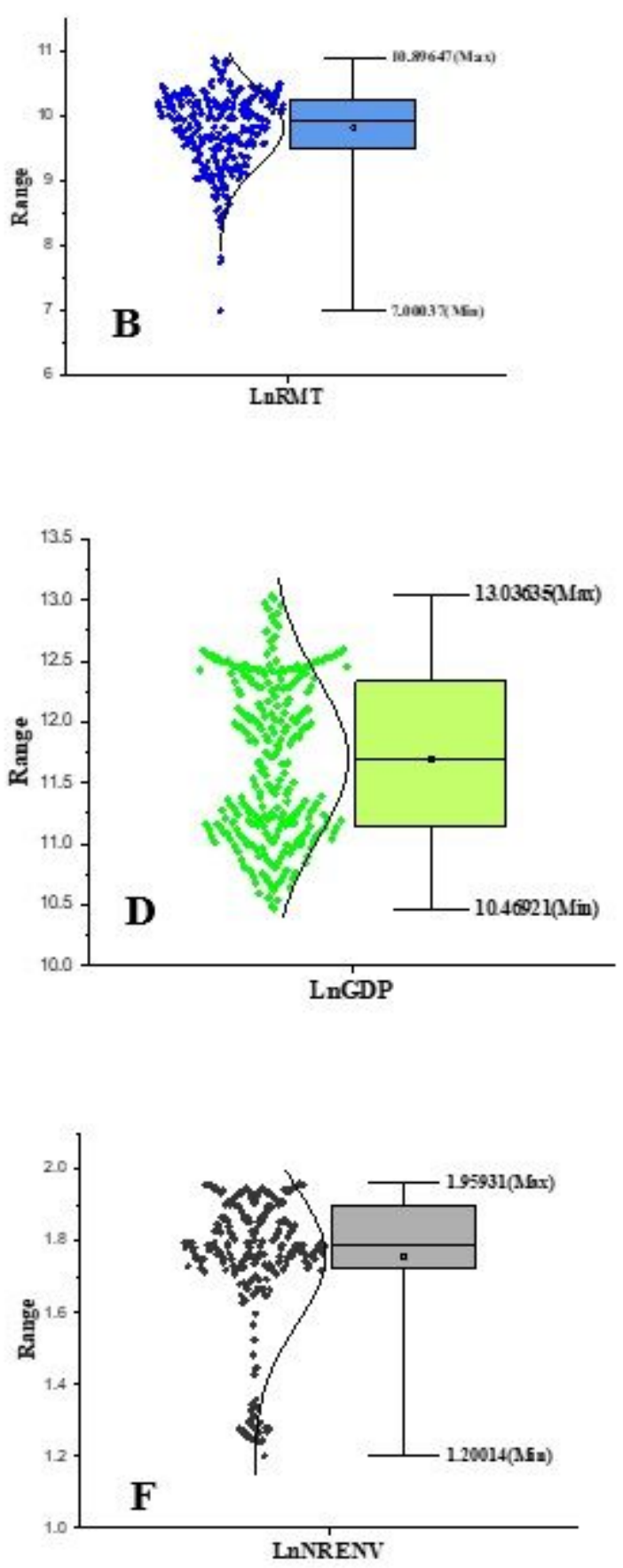

Figure 3

Box-plot summery descriptive statistics of our key variables. (A) LnEFP (B) LnRMT (C) LnFDI (D) LnGDP (E) LnRENV (F) LnNRENV 


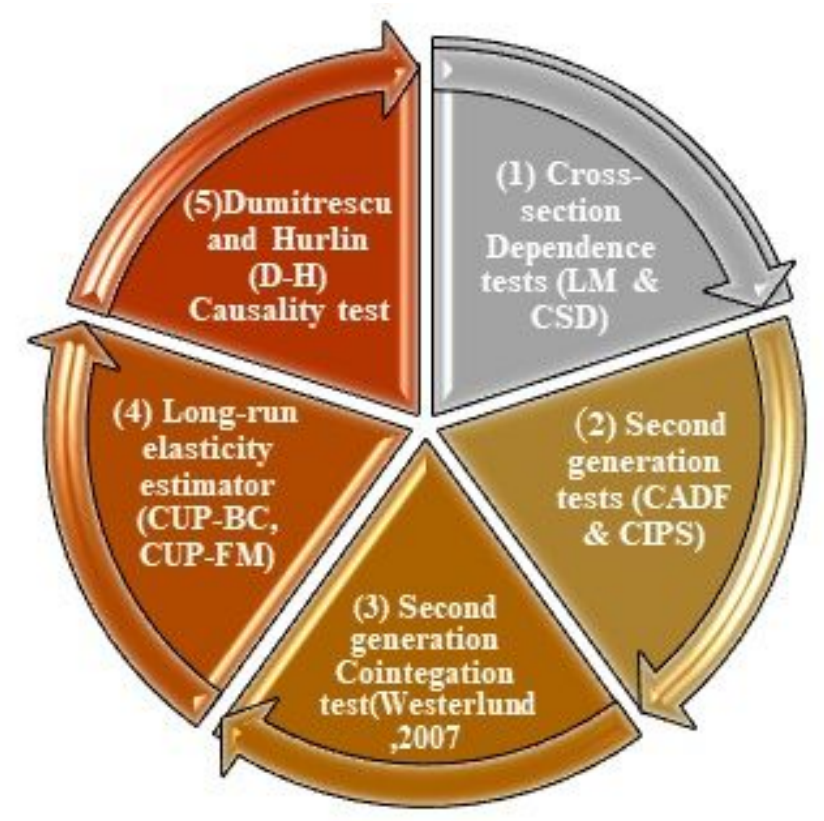

Figure 4

Road map of econometric modeling strategy

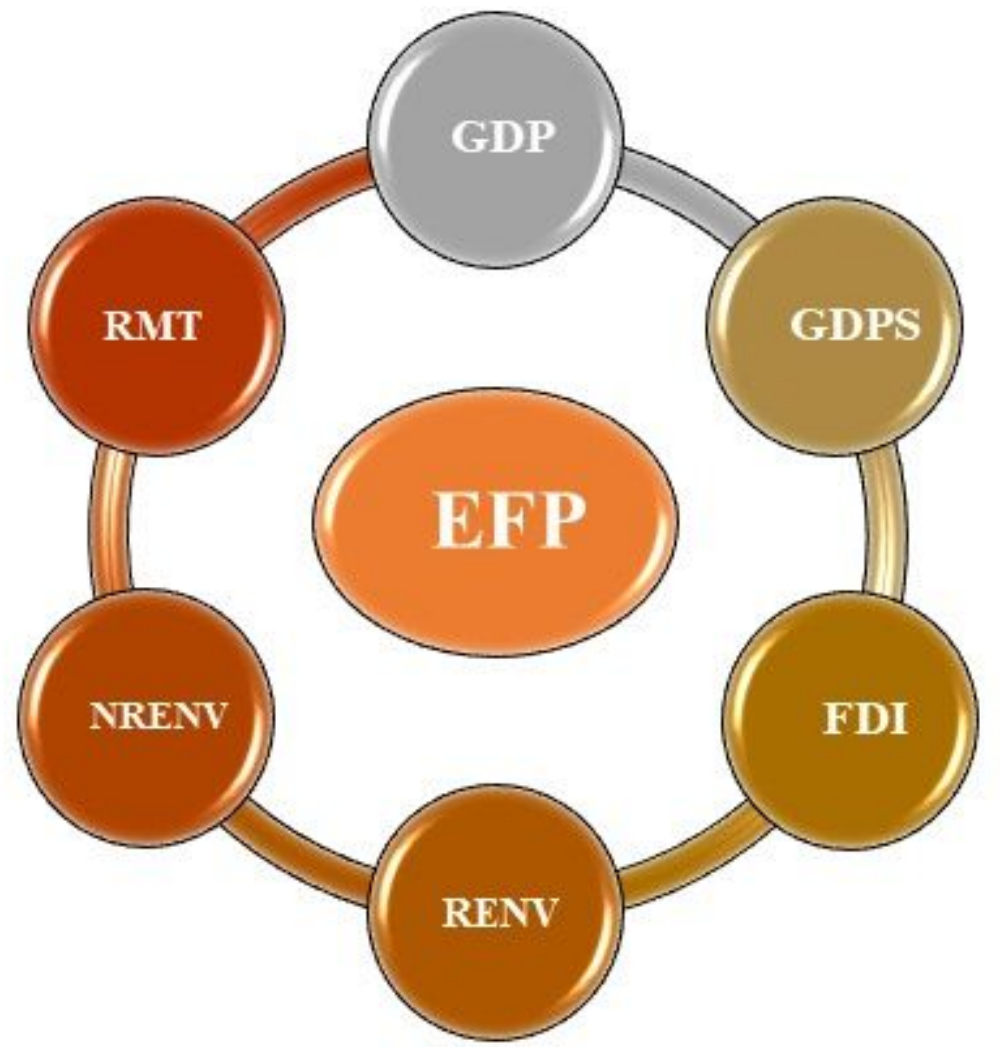

Figure 5

Graphical appearance of empirical results 


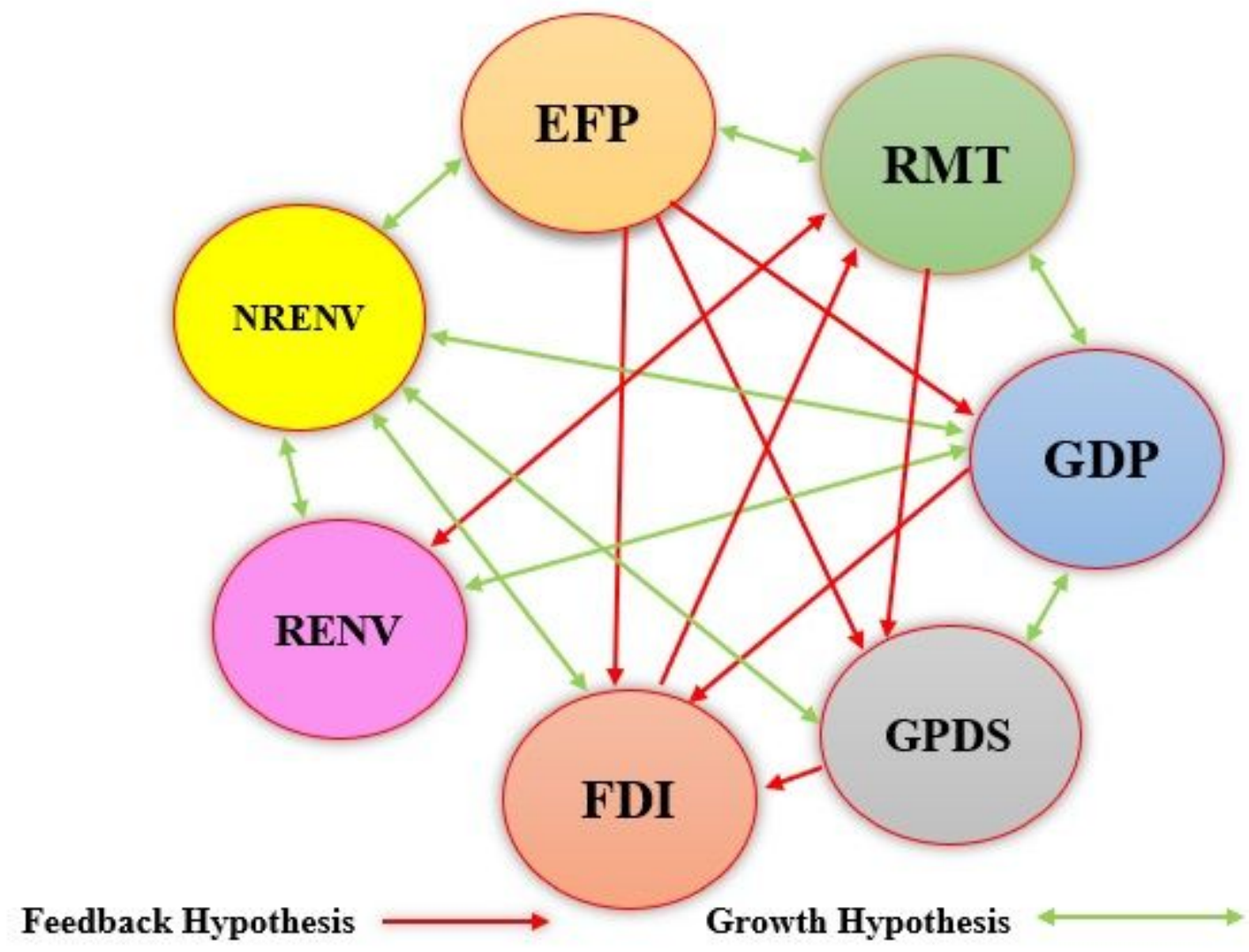

Figure 6

Causality association for top remittances countries 